\title{
New agents and regimens for diffuse large $B$ cell lymphoma
}

\author{
Liang Wang ${ }^{1,2^{*}}$, Lin-rong $\mathrm{Li}^{3}$ and Ken H. Young ${ }^{4^{*}}$ (B)
}

\begin{abstract}
As a widely recognized standard regimen, R-CHOP (rituximab plus cyclophosphamide, doxorubicin, vincristine, and prednisone) is able to cure two-thirds patients with diffuse large B cell lymphoma (DLBCL), and the remaining patients suffer from refractory or relapsed disease due to resistance to R-CHOP and fare poorly. Unsatisfied outcomes for those relapsed/refractory patients prompted efforts to discover new treatment approaches for $D L B C L$, including chimeric antigen receptor T cells, bispecific T cell engagers, immunomodulatory drugs, immune checkpoint inhibitors, monoclonal antibodies, antibody-drug conjugates, molecular pathway inhibitors, and epigenetic-modifying drugs. Herein, up-to-date data about the most promising treatment approaches for DLBCL are recapitulated, and novel genetic classification systems are introduced to guide individualized treatment for DLBCL.
\end{abstract}

Keywords: Diffuse large B cell lymphoma, Chimeric antigen receptor T cells, Immunotherapy, Chemoresistance, Novel agents, Genetic classification

\section{Introduction}

Diffuse large B cell lymphoma (DLBCL) is the most common subtype of lymphoma in adults worldwide, composing about one-third of non-Hodgkin lymphomas (NHLs) diagnosed each year [1], and it represents a considerable socioeconomic burden affecting millions of people [2]. CHOP (cyclophosphamide, doxorubicin, vincristine, and prednisone) regimen has been used for more than 40 years, and rituximab was approved by the US Food and Drug Administration (FDA) in 2006 for use as firstline treatment of patients with DLBCL in combination with $\mathrm{CHOP}$. Thereafter, $\mathrm{R}-\mathrm{CHOP}$ regimen has become the standard of care for patients with newly diagnosed DLBCL, even though patients with non-germinal center $B$ cell (non-GCB) subtype of DLBCL have significantly inferior outcomes than their GCB subtype counterparts

\footnotetext{
*Correspondence: wangliangtrhos@126.com; ken.young@duke.edu ${ }^{1}$ Department of Hematology, Beijing TongRen Hospital, Capital Medical University, Beijing 100730, China

${ }^{4}$ Division of Hematopathology, Department of Pathology, Duke University Medical Center and Cancer Institute, Durham, NC 27710, USA

Full list of author information is available at the end of the article
}

treated with R-CHOP [3]. In recent years, several randomized clinical trials have been conducted by adding novel targeted agents to R-CHOP (the so-called $\mathrm{R}-\mathrm{CHOP}+\mathrm{X}$ mode) in order to improve outcomes for patients with non-GCB or activated B-cell-like $(\mathrm{ABC})$ subtype of DLBCL, such as bortezomib [4], lenalidomide [5], or ibrutinib [6]. However, none of these targeted agents have been found to confer benefits in these trials. Moreover, dose-adjusted EPOCH (etoposide, prednisone, vincristine, cyclophosphamide, and doxorubicin) plus rituximab (DA-EPOCH-R) also failed to show improvement in survival outcomes for patients with DLBCL in a phase III randomized study (CALGB 50303) [7]. Standard R-CHOP regimen is able to cure two-thirds patients of DLBCL, and the remaining patients suffer from refractory or relapsed disease due to resistance to $\mathrm{R}-\mathrm{CHOP}$ and fare poorly [8]. The international SCHOLAR-1 study reported the median overall survival (OS) to be only 6.3 months for patients who were refractory to first-line treatment [9].

Poor outcomes for patients who failed R-CHOP regimen prompted efforts to discover new treatment approaches for DLBCL, both up-front and at the time

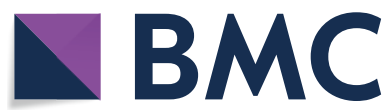

(c) The Author(s) 2020. Open Access This article is licensed under a Creative Commons Attribution 4.0 International License, which permits use, sharing, adaptation, distribution and reproduction in any medium or format, as long as you give appropriate credit to the original author(s) and the source, provide a link to the Creative Commons licence, and indicate if changes were made. The images or other third party material in this article are included in the article's Creative Commons licence, unless indicated otherwise in a credit line to the material. If material is not included in the article's Creative Commons licence and your intended use is not permitted by statutory regulation or exceeds the permitted use, you will need to obtain permission directly from the copyright holder. To view a copy of this licence, visit http://creativecommons.org/licenses/by/4.0/. The Creative Commons Public Domain Dedication waiver (http://creativeco mmons.org/publicdomain/zero/1.0/) applies to the data made available in this article, unless otherwise stated in a credit line to the data. 
of relapse. With hundreds of clinical trials underway, the landscape for DLBCL treatments has become increasingly crowded. In recent years, several agents or approaches have received the FDA approval for DLBCL, including polatuzumab vedotin, selinexor, tafasitamab, tisagenlecleucel, and axicabtagene ciloleucel (Table 1). Together, the therapeutics targeting immune checkpoints, tumor microenvironment, molecular signaling pathways, and epigenetic aberrations, as well as cellular immunotherapy, constitute the new landscape of treatments for DLBCL. This review focuses on available data about the most promising and potent agents now in clinical testing and provides expertise on individualized treatment for DLBCL according to novel genetic and molecular classifications.

\section{Immunotherapy}

\section{Chimeric antigen receptor T cells and natural killer (NK)}

cells

\section{Anti-CD19 CAR T cells}

Chimeric antigen receptor (CAR) $\mathrm{T}$ cells are rapidly emerging as a promising cellular immunotherapy in relapsed/refractory ( $r / r)$ DLBCL (Figs. 1, 2). The potent therapeutic efficacy of axicabtagene ciloleucel (axi-cel, marketed as Yescarta) [10], lisocabtagene maraleucel (liso-cel) [11], and tisagenlecleucel (marketed as Kymriah) [12] has been demonstrated in the context of CD19-directed CAR T cell therapy. In ZUMA-1 study, 101 patients of refractory aggressive B cell NHL with a median of three prior lines of treatment received at least $1.0 \times 10^{6} \mathrm{CAR}$-positive $\mathrm{T}$ cells $/ \mathrm{kg}$, and the investigator-assessed ORR was $83 \%$, and CR rate was $54 \%$ [10]. The 2-year follow-up data from ZUMA-1 indicated that axi-cel could obtain durable responses and significantly improve the $\mathrm{OS}$ with a manageable long-term safety profile in patients with $\mathrm{r} / \mathrm{r}$ DLBCL [13]. Another 93 patients who were ineligible or had disease progression after ASCT received tisagenlecleucel, and the best ORR was $52 \%$, with a CR rate of $40 \%$. At 1 year after initial response, the estimated relapse-free survival rate was $65 \%$, indicating a durable response with tisagenlecleucel [12]. Compared with historic data, these CAR T cell products have offered unexpected durable responses in patients with heavily pretreated DLBCL [14], which promoted the approval of Yescarta and Kymriah by FDA. With improved access to these CAR T cell products, patients of $r / r$ DLBCL may be treated with CAR $T$

Table 1 FDA-approved agents for the treatment of diffuse large B cell lymphoma

\begin{tabular}{|c|c|c|c|c|c|}
\hline Agent & Approved date & Study & Dose schedule $^{a}$ & $\begin{array}{l}\text { Number } \\
\text { of patients }^{a}\end{array}$ & Efficacy $^{a}$ \\
\hline Tafasitamab-cxix (Monjuvi) & July 31, 2020 & NCT02399085 & $\begin{array}{l}12 \mathrm{mg} / \mathrm{kg} \text { as an intravenous infu- } \\
\text { sion according to the following } \\
\text { dosing schedule } \\
\text { Cycle } 1 \text { : Days } 1,4,8,15 \text {, and } 22 \text { of } \\
\text { the } 28 \text {-day cycle } \\
\text { Cycles } 2 \text { and } 3 \text { : Days } 1,8,15 \text {, and } \\
22 \text { of each } 28 \text {-day cycle } \\
\text { Cycle } 4 \text { and beyond: Days } 1 \text { and } \\
15 \text { of each } 28 \text {-day cycle }\end{array}$ & 80 & ORR: 55\%; CR: 37\% \\
\hline Selinexor (XPOVIO) & June 22, 2020 & NCT02227251 & $\begin{array}{l}60 \text { mg orally on days } 1 \text { and } 3 \text { of } \\
\text { each week }\end{array}$ & 134 & CR: 13\%; ORR: 29\% \\
\hline Polatuzumab vedotin-piiq (Polivy) & June 10, 2019 & NCT02257567 & $\begin{array}{l}1.8 \mathrm{mg} / \mathrm{kg} \text { for six } 21 \text {-day cycle with } \\
\text { bendamustine and a rituximab } \\
\text { product }\end{array}$ & 80 & CR: 40\%; ORR: 63\% \\
\hline Tisagenlecleucel (Kymriah) & May 1, 2018 & NCT02445248 & $\begin{array}{l}0.6-6.0 \times 10^{8} \text { CAR-positive viable } \\
\text { T cells }\end{array}$ & 68 & CR: 32\%; ORR: 50\% \\
\hline Axicabtagene ciloleucel (Yescarta) & October 18, 2017 & NCT02348216 & $\begin{array}{l}2.0 \times 10^{6} / \mathrm{kg} \text { CAR-positive viable T } \\
\text { cells (maximum } 2 \times 10^{8} \text { ) }\end{array}$ & 108 & CR: 51\%; ORR: 72\% \\
\hline $\begin{array}{l}\text { Hyaluronidase human and rituxi- } \\
\text { mab (RITUXAN HYCELA) }\end{array}$ & June 22, 2017 & NCT01649856 & $\begin{array}{l}1400 \text { mg subcutaneous rituximab } \\
\text { and 23,400 units hyaluronidase } \\
\text { human, with CHOP }\end{array}$ & 381 & CR: 51\%; ORR: 83\% \\
\hline \multirow[t]{3}{*}{ Rituximab (Rituxan) } & \multirow[t]{3}{*}{ February 10, 2006} & LNH 98-5/GELA & rituximab 375 mg/m² with CHOP & 399 & CR:75\%; 2-y OS: 69\% \\
\hline & & E4494 & rituximab 375 mg/m² with CHOP & 632 & 2-y OS: 74\%; PFS: 3.1 years \\
\hline & & MInT & $\begin{array}{l}\text { rituximab } 375 \text { mg/mm² with } \\
\text { CHOP/CHOP-like regimens }\end{array}$ & 823 & $2-y$ OS: $95 \%$ \\
\hline
\end{tabular}

$C R$ complete response, ORR objective response rate, EFS event-free survival, 2-y OS overall survival at 2 years, PFS progression-free survival, $C H O P$ cyclophosphamide, doxorubicin, vincristine, and prednisone, CAR chimeric antigen receptor

a Refers to the FDA approval data posted on http://www.fda.gov/drugs 


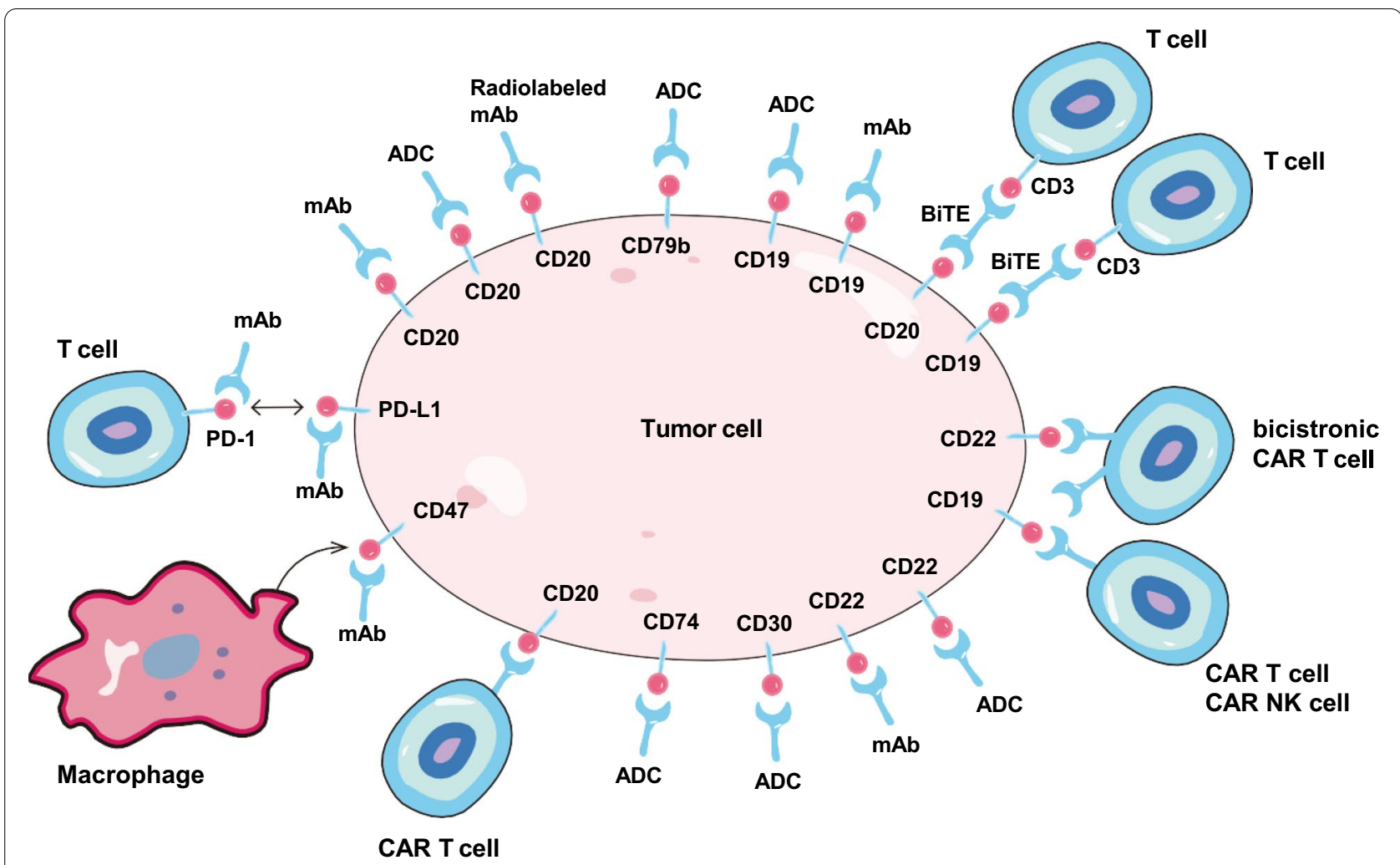

Fig. 1 Novel agents and strategies targeting DLBCL cell surface antigens. mAb monoclonal antibody, ADC antibody-drug conjugate, BiTE bispecific T cell engager, CAR chimeric antigen receptor, NK natural killer, PD-1 programmed cell death protein 1

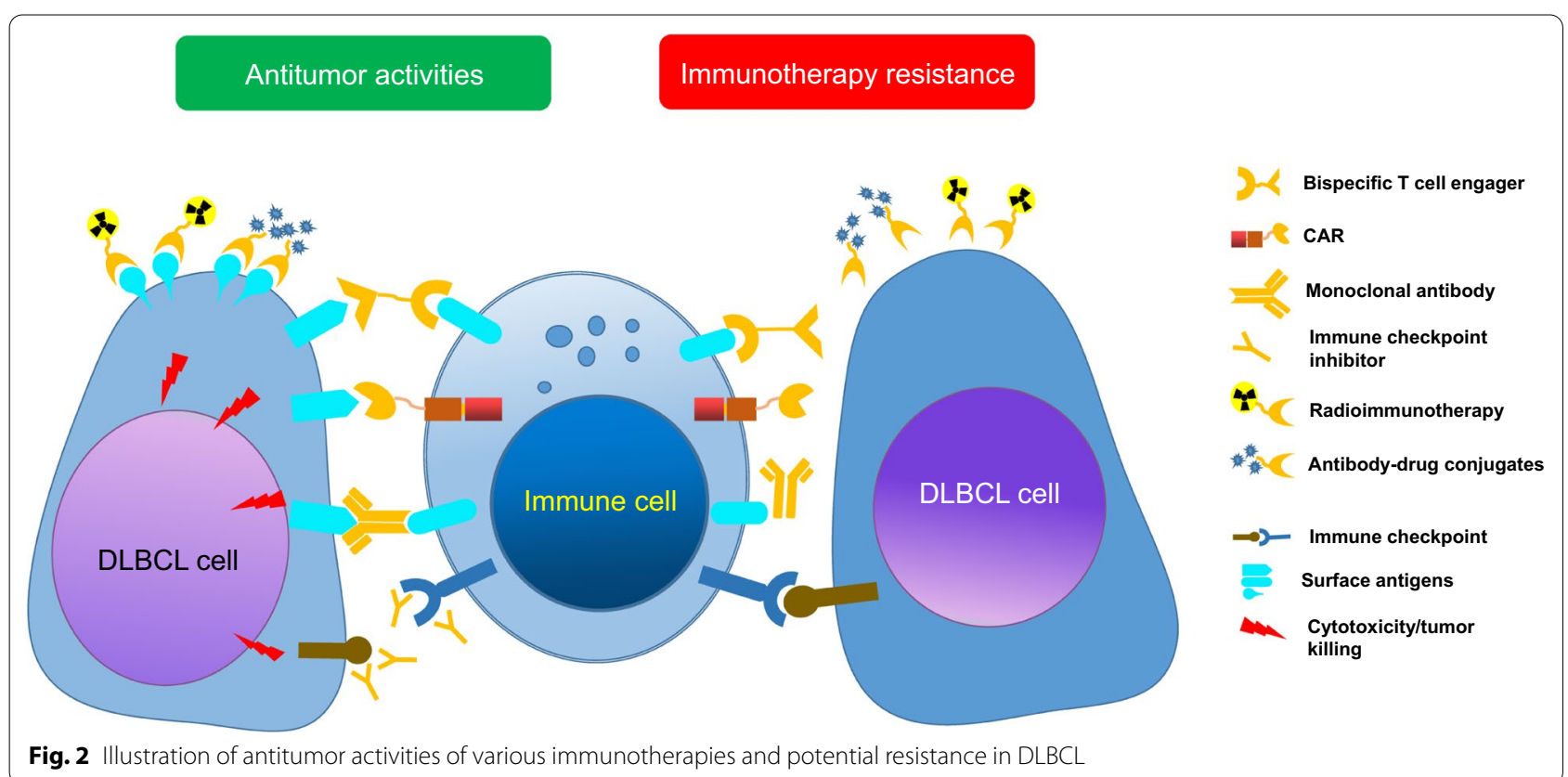


cell therapy at second-line scenario, or even as first-line treatment for patients with double-hit lymphoma.

\section{Dual CAR T cells or combination with immune checkpoint inhibitors}

However, despite notable clinical responses, modest durability of responses, treatment-related toxicities, and time-consuming production are major obstacles limiting the clinical use of autologous CAR $\mathrm{T}$ cell therapy. Relapses after CD19 CAR T cell therapies are partially due to CD19 loss (Fig. 2) or programmed death ligand 1 (PD-L1) upregulation $[15,16]$. In this regard, CAR T cells engineered to secrete human anti-PD-L1 antibodies, and dual CAR T cells as well as incorporation of immune checkpoint inhibitors are considered. For the treatment of B cell lymphomas, dual CAR T cells targeting CD19 and CD20 or CD22 are appealing. In a phase 1 trial, a bispecific CAR $\mathrm{T}$ product targeting CD19 and CD22 (Fig. 1) achieved 60\% ORR in 5 patients with $\mathrm{r} / \mathrm{r}$ DLBCL (1 CR and $2 \mathrm{PR}$ ) with tolerable toxicities [17]. Moreover, combination of anti-CD19 and anti-CD20 CAR T cells achieved an overall response rate (ORR) of $81.0 \%$ and CR rate of $52.4 \%$ in 21 patients with $\mathrm{r} / \mathrm{r}$ DLBCL [18]. It was reported that armed CAR $\mathrm{T}$ cells empowered to secrete anti-PD-L1 antibodies could resist $\mathrm{T}$ cell exhaustion and improve efficacy against renal cell carcinoma in mice model [19]. Programmed cell death protein 1 (PD1) blockade with pembrolizumab was safe and efficient in some patients with DLBCL progression after CD19
CAR T cell therapy [20]. The first bicistronic anti-CD19/ CD22 CAR T cells AUTO3 followed by pembrolizumab showed acceptable safety profiles in a phase $1 / 2$ trial. In patients who received at least $150 \times 10^{6} \mathrm{CAR} \mathrm{T}$ cells and pembrolizumab at day-1 $(n=8)$, the ORR was $75 \%$, with a CR rate of $63 \%$ [21]. Moreover, axi-cel in combination with PD-L1 blockade by atezolizumab showed manageable safety profiles and preliminary efficacy, according to the result of ZUMA-6 [22]. Thus, combination of CAR $\mathrm{T}$ cell therapy and PD-1/PD-L1 blockade seems feasible and promising in the treatment of $r / r$-DLBCL (Table 2 ).

\section{Universal CAR T cells}

Considering the frail condition of some patients and deficient $\mathrm{T}$ cell functions due to previous heavy treatments, clinical trials exploring CAR $\mathrm{T}$ cell therapy in the firstline (NCT03761056, ZUMA-12) and second-line settings (NCT03391466, NCT04161118, NCT03570892, NCT03575351, NCT03483103) are underway. Furthermore, allogeneic anti-CD19 CAR T cells from healthy donors are recognized to be an effective alternative to patients' exhausted T cells, as long as the endogenous TCR on the allogeneic CAR T cells is edited through various gene editing technologies in order to avoid alloreactivity of donor-derived $\mathrm{T}$ cells. A universal CAR T cell product targeting CD19 (UCART19) has been developed to treat $r / r$ B cell acute lymphoblastic leukemia with promising efficacy and manageable toxicities [23]. Some

Table 2 Summary of CAR T cell results in diffuse large B cell lymphoma

\begin{tabular}{|c|c|c|c|c|c|c|c|c|}
\hline Target & Agent & Study & Study phase & $\begin{array}{l}\text { Number of DLBCL } \\
\text { patients (treated) }\end{array}$ & Dose & ORR (\%) & CR (\%) & References \\
\hline CD19 & $\begin{array}{l}\text { Axicabtagene cilo- } \\
\text { leucel }\end{array}$ & $\begin{array}{l}\text { ZUMA-1 } \\
\text { (NCT02348216) }\end{array}$ & $1 / 2$ & 101 & $\begin{array}{l}2.0 \times 10^{6} \text { CART } \\
\text { cells } / \mathrm{kg}\end{array}$ & 83 & 58 & {$[13]$} \\
\hline CD19 & $\begin{array}{l}\text { axicabtagene } \\
\text { ciloleucel (in } \\
\text { combination with } \\
\text { atezolizumab) }\end{array}$ & $\begin{array}{l}\text { ZUMA-6 } \\
\text { (NCT02926833) }\end{array}$ & 1 & 12 & $\begin{array}{l}2.0 \times 10^{6} \mathrm{CART} \\
\text { cells } / \mathrm{kg}\end{array}$ & 90 & 60 & {$[22]$} \\
\hline CD19 & tisagenlecleucel & $\begin{array}{l}\text { JULIET } \\
\text { (NCT02445248) }\end{array}$ & 2 & 93 & $\begin{array}{l}0.1-6 \times 10^{8} \text { CART } \\
\text { cells }\end{array}$ & 52 & 40 & {$[12]$} \\
\hline CD19 & $\begin{array}{c}\text { lisocabtagene } \\
\text { maraleucel }\end{array}$ & $\begin{array}{l}\text { TRANSCEND } \\
\text { NHL } 001 \\
\text { (NCT02631044) }\end{array}$ & 1 & 268 & $\begin{array}{l}50-150 \times 10^{6} \text { CAR } \\
\text { T cells }\end{array}$ & 73 & 53 & {$[139]$} \\
\hline CD19 & CTL019 & NCT02030834 & $2 a$ & 28 & $\begin{array}{l}1.79-5.00 \times 10^{6} \mathrm{CAR} \\
\text { T cells }\end{array}$ & 64 & 43 & {$[11]$} \\
\hline CD19 & ET019003 & NCT04014894 & 1 & 6 & $\begin{array}{l}2-3 \times 10^{6} \text { CART } \\
\text { cells } / \mathrm{kg}\end{array}$ & 100 & - & {$[140]$} \\
\hline CD19 & FMC63-28Z & NCT00924326 & $1 / 2$ & 7 & $\begin{array}{l}1-5 \times 10^{6} \text { CART } \\
\text { cells } / \mathrm{kg}\end{array}$ & 85 & 71 & {$[141]$} \\
\hline CD19/CD22 & $\begin{array}{l}\text { AUTO3 (in combina- } \\
\text { tion with pem- } \\
\text { brolizumab) }\end{array}$ & $\begin{array}{l}\text { ALEXANDER } \\
\text { (NCT03287817) }\end{array}$ & $1 / 2$ & 24 & $50 \times 10^{6}$ CART cells & 57 & 29 & {$[21]$} \\
\hline
\end{tabular}


Table 3 Summary of antibody-drug conjugates and bispecific antibodies results in diffuse large B cell lymphoma

\begin{tabular}{|c|c|c|c|c|c|c|c|c|}
\hline Target & Drug & Toxin & Combined agents & Study & Study phase & No. & Efficacy & References \\
\hline CD19/CD3 & Blinatumomab & - & R-chemotherapy & $\begin{array}{l}\text { NCT } \\
03023878\end{array}$ & 2 & 30 & ORR 89\% & {$[27]$} \\
\hline CD19 & Coltuximab ravtansine & DM4 & - & $\begin{array}{l}\text { NCT } \\
01472887\end{array}$ & 2 & 61 & $\begin{array}{l}\text { ORR 44\% } \\
\text { CR 15\% }\end{array}$ & [71] \\
\hline CD19 & Loncastuximab tesirine & SG3199 & - & $\begin{array}{l}\text { NCT } \\
02669017\end{array}$ & 1 & 63 & $\begin{array}{l}\text { ORR 55\% } \\
\text { CR 37\% }\end{array}$ & [72] \\
\hline CD20 & MT-3724 & SLTA & - & $\begin{array}{l}\text { NCT } \\
02361346\end{array}$ & 1 & 13 & $\begin{array}{l}\text { ORR 30\% } \\
\text { CR 10\% }\end{array}$ & [57] \\
\hline CD20 & Ibritumomab tiuxetan & Yttrium-90 & $\begin{array}{l}\text { Combined with } R \\
\text { as maintenance } \\
\text { therapy }\end{array}$ & $\begin{array}{l}\text { NCT } \\
00070018\end{array}$ & 2 & 33 & $\begin{array}{l}5 \text {-y OS 87\% } \\
5 \text {-y PFS 82\% }\end{array}$ & [59] \\
\hline CD20 & Tositumomab & lodine-131 & $\mathrm{R}-\mathrm{CHOP}$ & $\begin{array}{l}\text { NCT } \\
00107380\end{array}$ & 2 & 86 & $\begin{array}{l}\text { ORR 86\% CR 61\% } \\
\text { 2-yPFS69\% } \\
\text { 2-y OS 77\% }\end{array}$ & {$[61]$} \\
\hline CD20/CD3 & RG6026 & - & Obinutuzumab & $\begin{array}{l}\text { NCT } \\
03075696\end{array}$ & $1 b$ & 28 & $\begin{array}{l}\text { ORR 48\% } \\
\text { CR 43\% }\end{array}$ & {$[30]$} \\
\hline CD20/CD3 & Mosunetuzumab & - & - & $\begin{array}{l}\text { NCT } \\
02500407\end{array}$ & $1 / 1 b$ & 55 & $\begin{array}{l}\text { ORR 33\% } \\
\text { CR 21\% }\end{array}$ & {$[31]$} \\
\hline CD20/CD3 & REGN1979 & - & - & $\begin{array}{l}\text { NCT } \\
02290951\end{array}$ & 1 & 53 & $\begin{array}{l}\text { ORR 33\% } \\
\text { CR 18\% }\end{array}$ & [32] \\
\hline CD22 & Pinatuzumab vedotin & MMAE & Rituximab & $\begin{array}{l}\text { NCT } \\
01691898\end{array}$ & 2 & 42 & ORR 60\% CR 26\% & {$[65]$} \\
\hline CD22 & $\begin{array}{l}\text { Inotuzumab ozo- } \\
\text { gamicin }\end{array}$ & Calicheamicin & Rituximab & $\begin{array}{l}\text { NCT } \\
00299494\end{array}$ & $1 / 2$ & 42 & $\begin{array}{l}\text { ORR } 74 \% \\
2 \text {-y EFS 42\% }\end{array}$ & [76] \\
\hline CD22 & Epratuzumab tetraxetan & Yttrium-90 & $\mathrm{R}-\mathrm{CHOP}$ & $\begin{array}{l}\text { NCT } \\
00906841\end{array}$ & 2 & 71 & $\begin{array}{l}2-y \text { EFS } \\
75 \%\end{array}$ & {$[142]$} \\
\hline CD30 & Brentuximab vedotin & MMAE & - & $\begin{array}{l}\text { NCT } \\
02280785\end{array}$ & 2 & 12 & $\begin{array}{l}\text { CR 17\% } \\
\text { DCR 50\% }\end{array}$ & [78] \\
\hline CD30 & Brentuximab vedotin & MMAE & - & $\begin{array}{l}\text { NCT } \\
01421667\end{array}$ & 2 & 49 & $\begin{array}{l}\text { ORR 44\% } \\
\text { CR 17\% } \\
\text { mPFS: } 4 \text { m }\end{array}$ & {$[80]$} \\
\hline CD74 & STRO-001 & Maytansinoid warhead & - & $\begin{array}{l}\text { NCT } \\
03424603\end{array}$ & 1 & 4 & $\begin{array}{l}\text { ORR 50\% } \\
\text { CR 25\% }\end{array}$ & [83] \\
\hline CD79b & Polatuzumab vedotin & MMAE & Rituximab & $\begin{array}{l}\text { NCT } \\
01691898\end{array}$ & 2 & 39 & $\begin{array}{l}\text { ORR 54\% } \\
\text { CR 21\% } \\
\text { mDoR } 13.4 \text { m }\end{array}$ & {$[65]$} \\
\hline CD79b & Polatuzumab vedotin & MMAE & $\mathrm{R}-\mathrm{CHP} / \mathrm{GHP}$ & $\begin{array}{l}\text { NCT } \\
01992653\end{array}$ & $1 b / 2$ & 66 & $\begin{array}{l}\text { ORR 89\% } \\
\text { CR } 77 \%\end{array}$ & {$[64]$} \\
\hline
\end{tabular}

MMAE monomethyl auristatin E, AEs adverse events, NEs neurologic events, SLTA Shiga-like toxin-I A1, NHL non-Hodgkin lymphoma, CRS cytokine release syndrome, $m D o R$ median duration of response, EFS event-free survival, $R$-CHOP rituximab, cyclophosphamide, doxorubicin, vincristine, and prednisone, $O R R$ objective response rate, $C R$ complete response, GHP obinutuzumab, doxorubicin, prednisone

other products with similar construct to UCART19 are under investigation in the treatment of $r / r$ DLBCL (NCT03939026) (Table 3).

\section{CAR-NK cells}

Similarly, genetically modified allogeneic NK cells represent another promising alternative for CAR $\mathrm{T}$ cell therapies. According to data from a phase $1 / 2$ trial, NK cells expressing anti-CD19 CAR and interleukin-15 (Fig. 1) resulted in responses in $73 \%$ (8/11) patients, of whom 4 with lymphoma and 3 with chronic lymphocytic leukemia had a $C R$. The responses were rapid without development of cytokine release syndrome (CRS), neurotoxicity, or graft-versus-host disease, and there was no increase in the levels of inflammatory cytokines, including interleukin-6, over baseline. Of note, the infused CAR-NK cells expanded and persisted at low levels for at least 1 year after infusion [24]. Thus, the HLA-mismatched NK cells originating from an allogeneic source may enable streamlining of the production process and universal access [24]. 


\section{CART cells with safety switches}

Management of toxicity while maintaining efficacy is a pivotal focus for CAR T cell therapies in development. Nearly half of the patients treated with axi-cel suffered from grade 3 or worse serious adverse events, including CRS and neurotoxicity [13]. The fourth-generation CAR $T$ cells usually contain additional safety measures, such as suicide genes (herpes simplex virus thymidine kinase, or caspase-9) or expression of cell surface antigens that can be targeted by monoclonal antibodies [25]. Moreover, a recombinant antibody-based bifunctional switch could be engineered to consist of a tumor antigen-specific Fab molecule at the one end and a peptide neo-epitope (PNE) at the other end, which can be bound exclusively by a PNE-specific switchable CAR $T$ cell [26]. These types of CAR $T$ cells are active to kill tumors only when they are given concurrently with the specific bifunctional switches, which make both the efficacy and toxicities of CAR T cells controllable.

Overall, diverse CAR T or NK cell products with different targets, different combinations, or different origins are enriching our arsenal in treating $\mathrm{r} / \mathrm{r}$-DLBCL, which may be put forward to second-line, or even first-line treatment for high-risk patients in the near future.

\section{Bispecific $T$ cell engagers}

Bispecific $T$ cell engagers (BiTEs, Figs. 1,2) are a new class of immunotherapy, which enhances the patients' immune cells to attack tumors by retargeting $\mathrm{T}$ cells to tumor cells. Blinatumomab, a CD19/CD3 BiTE, has demonstrated impressive efficacy against $B$ cell acute lymphoblastic leukemia (ALL), which led to its approval by FDA to treat r/r B-ALL. A phase 2 study evaluated the use of blinatumomab following rituximab-based immunochemotherapy in patients with newly diagnosed highrisk DLBCL $(n=28)$, and ORR was reported to be $89 \%$ [27]. Blinatumomab enabled 4 patients with no metabolic response after rituximab-based therapy to get objective responses after blinatumomab treatment, and minimal residual disease (MRD, assessed by plasma cell-free circulating tumor DNA) was converted from positive to negative in 9 patients following blinatumomab treatment, indicating blinatumomab consolidation as a potential option for newly diagnosed high-risk DLBCL [27]. In a phase 2 study, blinatumomab was used as second salvage in 41 patients with aggressive B cell lymphoma who failed platinum-based first salvage regimens, and got an ORR of $37 \%$ and CR rate of $22 \%$ after 12 weeks, indicating blinatumomab monotherapy to be an effective therapy that could bridge autologous stem cell transplantation (ASCT) in $r / r$ aggressive B cell lymphomas [28]. To further improve the efficacy of blinatumomab, combination with immunotherapy agents or immunomodulatory drugs to enhance the anticancer activity of host $\mathrm{T}$ cells is under investigation. Phase 1 studies with blinatumomab and pembrolizumab (NCT03340766) or lenalidomide (NCT02568553) are ongoing for patients with $\mathrm{r} / \mathrm{r}$ DLBCL. However, due to the short half-life of 2-4 h of blinatumomab, continuous intravenous infusion should be administrated for up to 28-70 days, which makes it extremely inconvenient in routine clinical practice. To extend the half-life and allow for a more convenient administration, a next-generation BiTE antibody construct-designated CD19 HLE BiTE (such as AMG 562) has been generated, with a half-life of about $210 \mathrm{~h}$, which enables once-weekly dosing [29]. The preclinical results of AMG 562 have demonstrated similar activity to blinatumomab, and it is now tested in clinical trials enrolling patients of DLBCL, mantle cell lymphoma, and follicular lymphoma (NCT03571828). Glofitamab, mosunetuzumab, and REGN1979 are all CD20/CD3 BiTEs with different construction that proved to be effective in $r / r$ DLBCL. Glofitamab (RG6026), a novel 2-to-1 format BiTE with 2 CD20-binding molecules and 1 CD3-binding molecule, demonstrated higher potency in vitro comparing to other CD20/CD3-BiTEs. In a phase 1 dose-escalating study (NCT03075696), a CR rate of $34.1 \%$ and ORR of $49.4 \%$ were achieved in 85 patients with aggressive B cell lymphoma who received the dosage of at least $10 \mathrm{mg}$ of glofitamab. Of note, more than half of the patients developed CRS and $16.7 \%$ of patients received tocilizumab to control CRS. Concurrent CD20 targeting by glofitamab and obinutuzumab led to an ORR of $48 \%$ and CR rate of $43 \%$ in $r / r$ aggressive NHL (including DLBCL) in a phase $1 \mathrm{~b}$ study [30]. A trial investigating the efficacy and safety of combined glofitamab and R-CHOP or G-CHOP is underway in untreated DLBCL (NCT03467373). According to results from a phase $1 / 1 \mathrm{~b}$ trial, patients with $\mathrm{r} / \mathrm{r}$ DLBCL treated with mosunetuzumab had an ORR of $33 \%$ and CR rate of $21 \%$. All patients with CR remained in remission at a median follow-up of 372 days [31]. REGN1979 monotherapy at dose $80 \mathrm{mg}$ to $320 \mathrm{mg}$ achieved CR in 5 of 8 patients with DLBCL, including 2 with CAR T cells failure [32]. Thus, BiTEs targeting CD3 and B cell surface antigens, such as CD19 and CD20, provide promising efficacy and tolerable safety profiles. Though not as potent as anti-CD19 CAR T cells, those BiTEs have the advantage of off-the-shelf availability, and serious adverse events could be easily controlled by discontinuing the drug. Future studies should be done concerning the optimal combination therapies and role of BiTEs in various settings of the disease, such as first-line induction, consolidation for high risk. 


\section{Immunomodulatory drugs}

Lenalidomide, as an immunomodulatory agent, is proved to have a variety of effects on the immune system and also alter tumor microenvironment by affecting the production and activity of cytokines involved in the maintenance of tumor growth and survival. Meanwhile, lenalidomide could exert direct tumor toxicities via binding to cereblon to inhibit downstream NF- $\mathrm{kB}$ signaling [33]. Combination of lenalidomide and $\mathrm{R}-\mathrm{CHOP} 21$ (R2-CHOP) seemed to provide benefits in several phase 2 studies, especially for the non-GCB and high-risk subgroups [34]. In REMARC study, for elderly patients responding to first-line R-CHOP, lenalidomide maintenance for 24 months prolonged PFS over placebo, although no OS benefit was found [35]. However, the phase 3 ROBUST study in untreated ABC-DLBCL did not meet the primary endpoint of PFS, though positive PFS trends favoring R2-CHOP21 were observed in those with high international prognostic index (IPI) scores and advanced disease stages [36]. Similarly, data from a phase 3 study of lenalidomide and R-miniCHOP showed no outcome improvement for patients aged over 80 years [37]. Meanwhile, the ECOG-ACRINI412 study achieved its primary endpoint, demonstrating significantly better PFS when using R-CHOP21 combined with lenalidomide [38]. Possible explanations for the different trial outcomes may include the different dose (lenalidomide $15 \mathrm{mg} \mathrm{d} 1-14$ in ROBUST and $25 \mathrm{mg} \mathrm{d} 1-10$ in ECOG-ACRIN 1412), eligibility criteria (exclusively $A B C$ subtype in ROBUST, and both $A B C$ and GCB in ECOG-ACRIN 1412), and time to treatment (within 31 days of diagnosis in ROBUST and within 21 days in
ECOG-ACRIN 1412), which indicates that the use of lenalidomide should not be restrained to ABC-DLBCL and timely treatment may benefit patients further for this aggressive lymphoma [38]. Notwithstanding, lenalidomide has been demonstrated to be effective in $\mathrm{r} / \mathrm{r}$ DLBCL as monotherapy [39] or combining salvage chemotherapies, such as R-ICE [40] and R-ESHAP [41]. The chemofree regimen R2 (rituximab plus lenalidomide) has also been shown to be active in elderly $\mathrm{r} / \mathrm{r}$ DLBCL patients, and durable CR was achieved in $35 \%$ patients [42], which made R2 an appealing choice for those ASCT-ineligible patients. Moreover, due to the ability of penetrating blood-brain barrier, lenalidomide has been proved to be highly active in treating primary central nervous system (CNS) lymphoma (PCNSL) [43, 44]. Thus, addition of lenalidomide to immunochemotherapy may reduce the risk of CNS relapses, which needs to be validated in the future.

\section{Immune checkpoint inhibitors (ICls)}

Immune evasion is a hallmark of DLBCL, where the B7-CD28 gene family plays a pivotal role. According to the data based on a total of 184 DLBCL biopsies, PD-1 (CD279) and PD-L1 (CD273, B7-DC) expressions (i.e., expressed on more than $5 \%$ of cells) on lymphoma cells were detected in $1.63 \%$ and $43.48 \%$ of patients, respectively, while their expressions on microenvironment cells were found in $11.41 \%$ and $26.09 \%$ of patients, respectively [45]. Several early phase trials are reported, testing multiple inhibitors targeting the most studied immune checkpoints both in the $r / r$ and in the frontline settings,

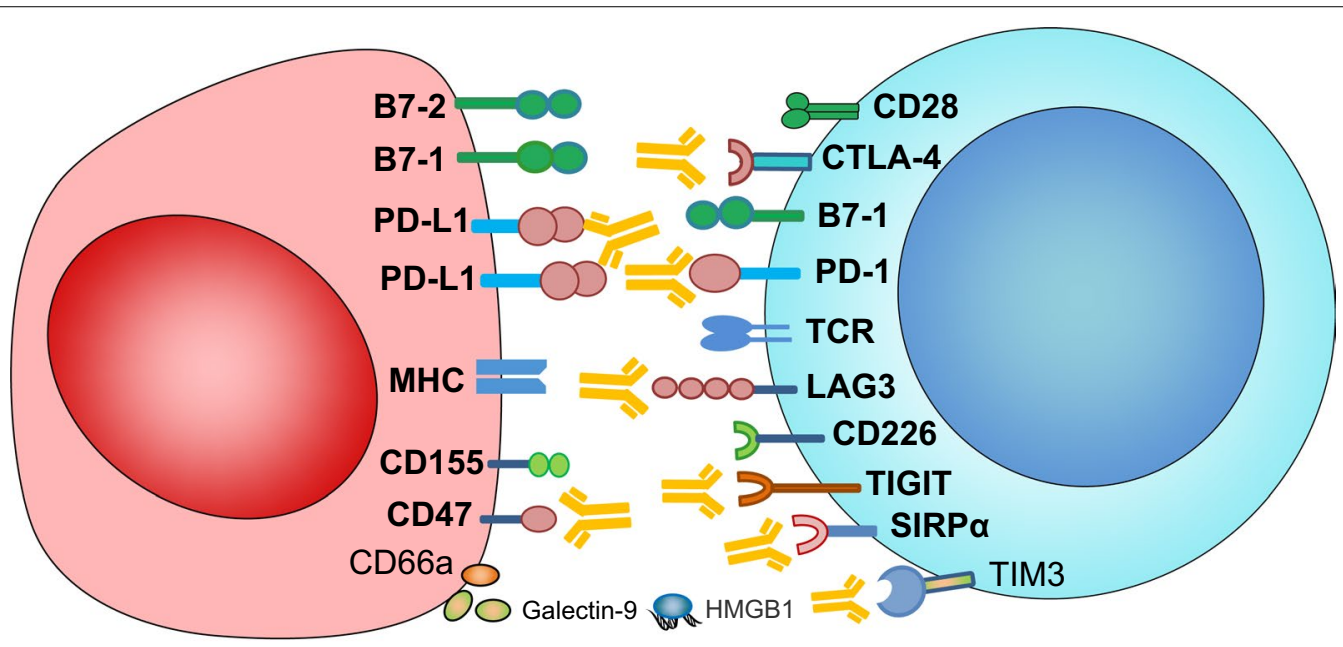

DLBCL or antigen-presenting cell

T cell or other immune cell

Fig. 3 Established and emerging immune checkpoint targets in DLBCL and corresponding blocking monoclonal antibodies as immune checkpoint inhibitors 
including pembrolizumab and nivolumab for PD-1, durvalumab, avelumab, and atezolizumab for PD-L1 (Fig. 1) [46]. However, only avelumab underwent phase 3 trial for combination therapies in $\mathrm{r} / \mathrm{r}$ DLBCL (NCT02951156), and no data from phase 3 trials are currently available. Apart from PD-1 and PD-L1, other molecular targets for novel immune checkpoint inhibitors (LAG-3, TIGIT, TIM-3, and VISTA) have been discovered continuously, but remained to be tested in DLBCL (Fig. 3) [47].

PD-1 blockade has been tested in $r / r$, post-ASCT consolidation, and first-line settings, either monotherapy or in combination mode. Nivolumab as monotherapy at dose $3 \mathrm{mg} / \mathrm{kg}$ showed an ORR rate of $36 \%$ and acceptable safety profiles in heavily pretreated patients with $\mathrm{r} / \mathrm{r}$ DLCBL $(n=11)$ [48]. An interesting use of checkpoint inhibition has evolved with the introduction of CAR T cell therapy. As aforementioned, atezolizumab or pembrolizumab following CD19 CAR T cell therapies was expected to tackle resistance, though further research is needed. Also, PD-1 blockade after ASCT was believed to leverage immune landscapes to decrease minimal residual disease. However, data from a phase 2 study showed that pembrolizumab consolidation given after ASCT did not improve the 18-month PFS rate (59\%) [49]. Just as rituximab does not provide clinical benefits when used as post-ASCT maintenance, checkpoint inhibitors face the same challenge. Post hoc analysis needs to be done to explore the specific subpopulation who benefited from ICIs therapy, such as PD-L1 amplification or mutation, etc. Thus, immunotherapy targeting PD-1/PD-L1 seems unsatisfactory (Fig. 2) when using as monotherapy, and indicative biomarkers should be explored further to launch precision medicine in a subset of DLBCL patients. Combination of pembrolizumab and R-CHOP (PR$\mathrm{CHOP}$ ) has been tested in 30 newly diagnosed DLBCL patients, resulting in the overall and complete response rate being $90 \%$ and $77 \%$, respectively. The 2-year PFS was $83 \%$ at a median follow-up of 25.5 months, and this regimen was well tolerated [50]. Meanwhile, higher expression of PD-L1 correlated with improved PFS, suggesting assessment of PD-L1 expression as a useful biomarker to identify patients who actually benefit from this first-line strategy.

Though PD1/PD-L1 blockade seems to have unimpressive efficacy in $r / r$ DLBCL, another immune checkpoint $\mathrm{CD} 47$, considered as macrophage checkpoint, has emerged to be a promising target (Fig. 1). CD47 upregulation on malignant cells reveals immune evasion and drug resistance, which was detected in $53.7 \%$ patients of DLBCL [51]. Hu5F9-G4 is a first-in-class CD47-directed monoclonal antibody (mAb) and macrophage checkpoint inhibitor that preferentially enables phagocytosis of DLBCL cells by CD47 blockade. This action could be augmented by rituximab through its Fc region [51]. The safety and efficacy profiles of the combination of Hu5F9G4 and rituximab were evaluated in a phase $1 \mathrm{~b} / 2$ study involving 63 patients with $\mathrm{r} / \mathrm{r}$ DLBCL. ORR was obtained by $39 \%(n=18)$ patients, and $20 \%(n=9)$ experienced CR. Duration of response was not reached at more than 20 months of follow-up. Adverse events were mostly grade 1 to 2 infusion reactions (38\%) and headache (34\%), whereas first-dose grade 3 anemia in $15 \%$ of patients was observed [52]. Moreover, dual blockade of CD47 and PD-L1 may be a potential synergistic therapy that can elicit both innate and adaptive immune response against tumors [53], which is worthy investigating in clinical trials (NCT04328831).

\section{Monoclonal antibodies and antibody-drug conjugates}

Since the approval of rituximab in the treatment of DLBCL in 2006, many novel agents targeting cell surface antigens have been developed and tested in DLBCL. Many $\mathrm{mAbs}$ are developed both in the unconjugated form and in the conjugated forms (Figs. 1, 2), where they are designed to conjugate to a cytotoxic payload (antibody-drug conjugate, $\mathrm{ADC}$ ), a radioactive molecule (radiolabeled $\mathrm{mAb}$ ), or another antibody (i.e., bispecific antibody) by a covalent linker. In the following, these novel antibodies are categorized according to different cell surface antigens (Fig. 1).

\section{CD20-directed agents}

In addition to first-generation rituximab, other CD20 mAbs currently used in the treatment of DLBCL include second-generation ofatumumab as well as third-generation obinutuzumab (GA-101). The alteration within molecular structures (e.g., Fc region) of CD20 mAbs enhanced binding affinity to CD20 antigen and antibody-dependent cell cytotoxicity (ADCC) [54]. However, G-CHOP (obinutuzumab plus CHOP) did not significantly improve PFS but resulted in more severe adverse events, compared with R-CHOP in previously untreated DLBCL [54]. Ofatumumab was well tolerated in the elderly, and combination of ofatumumab and miniCHOP was reported to achieve a 2 -year OS rate of $64.7 \%$ for DLBCL in patients aged 80 years or older [55]. Meanwhile, for those frail elderly patients who are poor candidates for R-CHOP chemotherapy, combination of ofatumumab and bendamustine demonstrated an ORR of $90.5 \%$ and CR of $33.3 \%$ with tolerable toxicities [56]. Overall, comparing with historic data of rituximab-based therapy, all these second-generation CD20 mAbs did not provide further benefits for DLBCL patients, and future patient resources should be put in clinical trials of CD20ADCs instead of CD20-mAbs. 
MT-3724 is a novel ADC directed against CD20, which is comprised of a single-chain variable fragment lined to Shiga-like toxin-1A, a ribosome-inactivating protein. Phase I trial of MT-3724 monotherapy in heavily pretreated DLBCL patients reported an ORR of $30 \%$ [57], with the phase II trial already being underway [58]. Radiolabeled CD20 mAbs currently used in clinical testing include ibritumomab tiuxetan (Zevalin) and tositumomab (Bexxar), chelated with yttrium-90 and iodine-131, respectively. Consolidation with Zevalin after $\mathrm{CHOP}$ plus radiotherapy achieved 5 -year OS of $87 \%$ and 5 -year PFS of $82 \%$ in high-risk patients with earlystage NHL including DLBCL [59]. For patients with limited-stage DLBCL who were interim-PET positive after 3 cycles of R-CHOP, involved-field radiation therapy (IFRT) followed by Zevalin consolidation resulted in 5-year PFS rate of $86 \%$ and OS rate of $93 \%$ in the S1001 study [60]. In the SWOG S0433 trial involving 84 patients with advanced-stage DLBCL, R-CHOP followed by Bexxar consolidation showed a 2-year PFS of $69 \%$ and 2-year OS of 77\% [61], indicating that consolidation therapy with those radiolabeled CD20 mAbs may provide benefits to patients of high-risk or advanced disease.

\section{CD79b-directed agents}

CD79b, a core component of the $\mathrm{B}$ cell receptor, plays a pivotal role in chronic-active $B$ cell receptor (BCR) signaling and canonical NF- $\mathrm{KB}$ signaling pathway of DLBCL survival, especially for the activated $B$ cell-like $(A B C)$ subtype [62]. Polatuzumab vedotin (DCDS4501A) is a novel CD79b-directed ADC with site-specific conjugation to MMAE. In 2019, combined polatuzumab vedotin with bendamustine and rituximab was approved by the FDA for patients with $\mathrm{r} / \mathrm{r}$ DLBCL after at least 2 prior therapies [63]. Beyond combination with rituximab, the replacement of vincristine with polatuzumab vedotin was tested in a multicenter phase Ib/II study with R-CHP or G (obinutuzumab)-CHP. Polatuzumab vedotin dosed $1.8 \mathrm{mg} / \mathrm{kg}$ showed overall acceptable safety profiles with 25/66 (38\%) patients experiencing grades 1 and 2 peripheral neuropathy and good efficacy (ORR 89\%; CR, 77\%) in previously untreated DLBCL [64]. Though ITAM (immunoreceptor tyrosine-based activation motif) mutation of CD79b was frequently recognized in $23 \%$ of $A B C$ $\mathrm{r} / \mathrm{r}$ DLBCL [62], the reported activities of polatuzumab vedotin showed no preference for any DLBCL cell-oforigin subtypes or CD79b expression [64, 65]. Giving the significant clinical activities and manageable safety profiles of polatuzumab vedotin, additional evaluation of polatuzumab vedotin with other agents (including lenalidomide, venetoclax, and obinutuzumab) in the $\mathrm{r} / \mathrm{r}$ setting is ongoing. Specifically, two phase III studies are now recruiting: POLARIX to compare polatuzumab vedotin plus $\mathrm{R}-\mathrm{CHP}$ with $\mathrm{R}-\mathrm{CHOP}$ alone in untreated DLBCL [66], and POLARGO evaluating polatuzumab vedotin in combination with R-GemOx (rituximab, gemcitabine, and oxaliplatin) in patients with $r / r$ DLBCL after at least 1 prior therapies [67].

\section{CD19-directed agents}

Recent results of the CD19 mAbs suggest that this therapeutic paradigm is finally showing promise for DLBCL. On July 31, 2020, the FDA approved the use of an Fcengineered CD19 mAb tafasitamab (MOR208, Monjuvi ${ }^{\circledR}$ ) combined with lenalidomide in $r / r$ DLBCL. In a phase IIa study investigating tafasitamab monotherapy for patients with $\mathrm{r} / \mathrm{r}$ DLBCL, 35 patients showed a 12-month PFS rate of $34.3 \%$, with a median duration of response (DoR) of 20.1 months [68]. In a single-arm phase II trial (L-MIND) for the combination of tafasitamab and lenalidomide, 80 non-transplant eligible patients with $\mathrm{r} / \mathrm{r}$ DLBCL showed a CR rate of $43 \%$, ORR rate of $60 \%$, and DoR of 21.7 months [69]. Given the significant clinical benefits, a phase III trial (NCT02763319) is now recruiting to compare tafasitamab versus rituximab in combination with bendamustine in adult patients with $\mathrm{r} / \mathrm{r}$ DLBCL. Inebilizumab, a humanized anti-CD19 monoclonal antibody, was tested as monotherapy in a phase 1 study, among which 6 patients with $\mathrm{r} / \mathrm{r}$ DLBCL were enrolled. The maximum tolerated dose was defined as $8 \mathrm{mg} / \mathrm{kg}$, and ORR was 50\% (1 CR and 2 PR) in patients with DLBCL [70].

Coltuximab ravtansine (SAR3419, huB4-DM4) represents a novel CD19-targeted ADC conjugated to a maytansinoid-derivate antimitotic payload DM4 through a disulfide linker. The clinical efficacy and safety of SAR3419 monotherapy were evaluated in a phase II multicenter study. Eighteen of 41 patients with $\mathrm{r} / \mathrm{r}$ DLBCL at dose $55 \mathrm{mg} / \mathrm{m}^{2}$ obtained ORR (43.9\%), with a median DoR of 4.7 months [71]. Another CD19-targeted ADC ADCT-402 (loncastuximab tesirine) comprising pyrrolobenzodiazepine dimer toxin showed early promise for patients DLBCL. Of the 51 patients with $\mathrm{r} / \mathrm{r}$ DLBCL who were treated at $120 \mathrm{mg} / \mathrm{kg}$ or above this dosage threshold, 28 (54.9\%) responded to ADCT-402, with a median DoR of 3.1 months for patients achieving PR. The DoR for CR patients was not reached with a median follow-up of 7.5 months [72]. Those CD19-targeted ADCsbased combination therapies are under study, which may provide new options for $r / r$ DLBCL.

\section{CD22-directed agents}

Epratuzumab is a CD22-directed monoclonal antibody with efficacy in both relapsed and untreated DLBCL [73]. When combined with rituximab, epratuzumab treatment 
led to an ORR of $67 \%$ and CR of $50 \%$ in 6 patients with $\mathrm{r} / \mathrm{r}$ DLBCL [74]. The 3-year event-free survival (EFS) and OS were $70 \%$ and $80 \%$, respectively, in patients with newly diagnosed DLBCL treated with epratuzumab plus standard R-CHOP [75]. After adjusting for IPI, the patients treated with epratuzumab plus $\mathrm{R}-\mathrm{CHOP}$ achieved significantly improved EFS, compared with those treated with R-CHOP [75]. However, no subsequent follow-up data or phase 3 RCT result was reported, suggesting that no potential extra benefit was provided by addition of epratuzumab to R-CHOP.

Pinatuzumab vedotin (DCDT2980S) is a CD22directed ADC conjugated to the antimitotic payload MMAE. Pinatuzumab vedotin alone at dose $2.4 \mathrm{mg} /$ $\mathrm{kg}$ yielded moderate efficacy, with an ORR of $36 \%$ and median DoR of 3.0 months observed in patients with $\mathrm{r} / \mathrm{r}$ DLBCL [65]. Combination of rituximab and pinatuzumab vedotin resulted in higher ORR and CR in patients with $\mathrm{r} / \mathrm{r}$ DLBCL, compared with single-agent pinatuzumab vedotin (ORR, $60 \%$ vs. $36 \%$; CR, $26 \%$ vs. $16 \%$, for combination vs. single agent, respectively) [65]. Inotuzumab ozogamicin (CMC-544) is another CD22-directed ADC conjugated to the DNA-damaging calicheamicin. A phase $1 / 2$ study of combining inotuzumab and rituximab reported an ORR of $74 \%$ in $\mathrm{r} / \mathrm{r}$ DLBCL patients [76], but the phase 3 trial (NCT01232556) of inotuzumab ozogamicin plus rituximab in $\mathrm{r} / \mathrm{r}$ DLBCL was discontinued for futility in 2013 when comparing with investigator's choice (IC). However, the favorable safety profiles of inotuzumab plus rituximab suggest this regimen may be appropriate for a specific patient populations [77]. A study of inotuzumab plus rituximab, cyclophosphamide, vincristine, and prednisolone in chemotherapynaïve patients with DLBCL who are not candidates for anthracycline-based treatment is currently recruiting (NCT01679119).

\section{CD30-directed agents}

Brentuximab vedotin (BV, SGN-35) is a potent CD30directed $\mathrm{ADC}$, which has been approved by the FDA for classical Hodgkin lymphoma, primary cutaneous anaplastic large cell lymphoma, and systemic anaplastic large-cell lymphoma. The efficacy of BV is under broad investigation in various subtypes of NHL, including DLBCL. CD30 was expressed on $20 \%$ or more tumor cells of about $14 \%$ of de novo DLBCL cases, though significant association between the response rate and CD30 expression in DLBCL was undefined [78, 79]. Single agent BV was active in $\mathrm{r} / \mathrm{r}$ DLBCL with variable levels of CD30 expression, and ORR occurred in $44 \%$ of DLBCL cases [80]. However, computer-assisted digital image analysis showed that a minimum CD30 expression threshold of $1 \%$ was required for antitumor properties in DLBCL [81].
Thus, it is recommended that CD30 immunostaining should be done routinely in DLBCL, and BV may provide a potential option for $\mathrm{r} / \mathrm{r}$ DLBCL with CD30 positivity.

\section{CD74-directed agents}

CD74 is a MHC class II chaperone broadly expressed on human immune cells and B cell lymphomas, which represents a promising target for treatment of DLBCL [82]. The novel CD74-directed ADC STRO-001 contains a humanized glycosylated antibody SP7219 and potent maytansinoid linker-warhead. STRO-001 is already being investigated in the first-in-human phase 1 , multicenter study (NCT03424603) for adults with advanced B cell malignancies, including $\mathrm{r} / \mathrm{r}$ DLBCL. Preliminary antitumor activity of STRO-001 observed in 4 patients with DLBCL was encouraging. One patient achieved a CR after 2 cycles but progressed after 6 cycles. An additional patient with DLBCL obtained a partial response after 3 cycles [83]. Though modest activity was demonstrated as monotherapy, further trials evaluating the efficacy of combination strategies should be done.

\section{Molecular pathway inhibitors}

Gene expression profiling analysis has defined $A B C$ and GCB as 2 major subtypes of DLBCL (about $50 \%$ and $30 \%$, respectively), according to cell of origin [84]. Aberrant expression and genetic disorders of CD79b, CARD11, MYD88, TNFAIP3, BCL-10, TRAF3, TRAF2, NFKBIA, and NFKBIE $(\mathrm{I} k \mathrm{B \varepsilon})$, in concordance with the prevalence of chronic-active $B$ cell receptor (BCR) signaling, JAK-STAT3 signaling, and canonical NF- $\kappa B$ signaling, were believed to underlie the inferior outcomes of $A B C$ DLBCL (Fig. 4) [85]. Notably, great heterogeneity exists in the entity of GCB or ABC. In 2018, Schmitz and colleagues identified 4 unique genetic subtypes in DLBCL (MCD, BN2, N1, and EZB) with distinct prognosis [85]. At the meantime, Chapuy et al. [86] identified 5 robust DLBCL clusters of discrete outcomes with coordinate genetic signatures. Moreover, George et al. [87] recently developed an algorithm that can classify a patient's lymphoma into one of seven genetic subtypes, which highlight the potential use of specific targeted agents and contribute to precision medicine. For example, the perturbation of proximal BCR signaling is suggested for MCD subtype, BCL-2 inhibitors for BN2, NF- $\mathrm{KB}$ signaling blockade for both $\mathrm{BN} 2$ and A53, along with the inhibition of JAK-STAT3 signaling for ST2 subtype [85-87]. In this section, we summarize the cross-linked signaling pathway intricacies at the intersection of DLBCL biology and the clinic. Rational molecular therapies targeting aberrant pathways in the clinical setting are carefully enumerated (Table 4) and discussed on the molecular basis. 


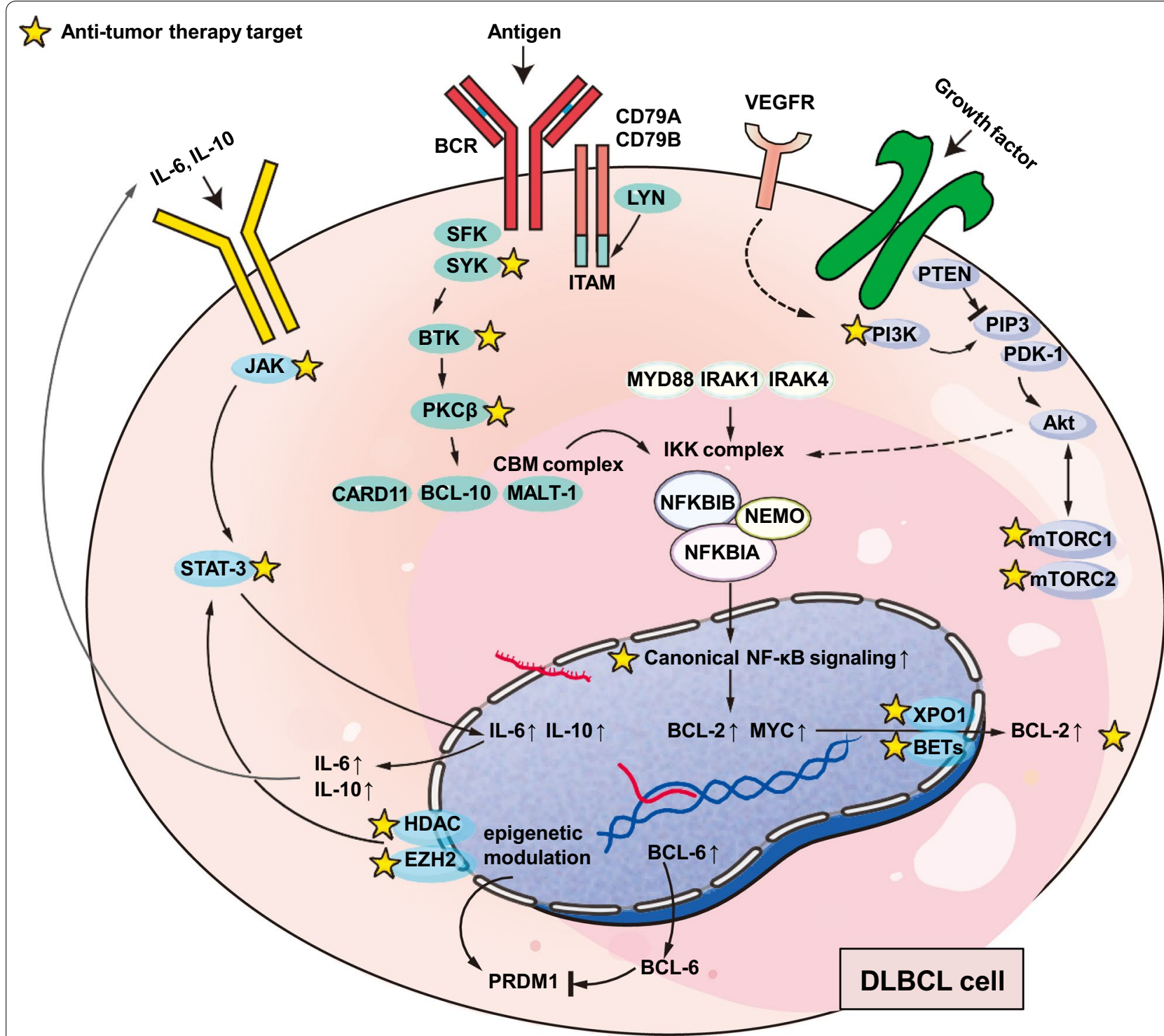

Fig. 4 Novel agents targeting molecular signaling pathways and epigenetic regulations. Distinct molecular aberrations classify DLBCL into different molecular subtypes and indicate individualized treatments, including BCR signaling pathways, BCL-2, JAK/STAT3 pathways, VEGFR, PI3K/Akt/mTOR pathways, NF-kB signaling pathways, as well as epigenetic regulators, such as HDAC, EZH2, and BET

\section{BCR signaling pathway inhibition}

Chronic-active BCR signaling is pivotal in the survival of almost all $\mathrm{ABC}$ DLBCLs, driven by frequent activating mutations of the immunoreceptor tyrosine-based activation motifs in CD79B and CD79A, or of the coiled-coil domain in CARD11 [62]. On the contrary, GCB DLBCLs were prone to present with a BCR-negative immunophenotype [88]. Molecular inhibitors targeting BCR-dependent ABC DLBCLs include: entospletinib and fostamatinib for spleen tyrosine kinase (SYK); ibrutinib, zanubrutinib, ARQ-531, LOXO-305, DTRMWXHS-12, and acalabrutinib for BTK; enzastaurin for protein kinase $C \beta$
(PKC $\beta$ ) (Fig. 4). Of note, SYK inhibitors showed limited single-agent activities in $\mathrm{r} / \mathrm{r}$ ABC DLBCL $[89,90]$. A better understanding of which patients would benefit from BCR blockade via SYK inhibition or other molecular therapeutics is important for their further development in DLBCL. For example, BTK inhibition killed upstream CD79-mutant DLBCL cells, but was dispensable for downstream CARD11-mutant DLBCL cells, which were susceptible to NF- $\mathrm{BB}$ pathway inhibitors [91]. Immunohistochemistry and genetic assessments are thereby recommended, in order to confirm the exact lesion in molecular pathways. 
Table 4 New molecular therapeutics and ongoing clinical trials in diffuse large B cell lymphoma

\begin{tabular}{|c|c|c|c|c|c|c|c|c|}
\hline Agent & Agent type & $\begin{array}{l}\text { Combined } \\
\text { agent }\end{array}$ & Study & Study phase & $\begin{array}{l}\text { Recruitment } \\
\text { status }\end{array}$ & $\begin{array}{l}\text { Enrollment } \\
\text { (estimated/ } \\
\text { actual) }\end{array}$ & Indication & $\begin{array}{l}\text { Results } \\
\text { for DLBCL }\end{array}$ \\
\hline Idelalisib & PI3K inhibitor & - & $\begin{array}{l}\text { NCT03576443 } \\
\text { (ILIAD) }\end{array}$ & 2 & Recruiting & 72 & $\begin{array}{l}\text { Relapsed GCB } \\
\text { DLBCL }\end{array}$ & - \\
\hline Copanlisib & $\begin{array}{l}\mathrm{PI} 3 \mathrm{Ka} / \delta \text { inhibi- } \\
\text { tor }\end{array}$ & Nivolumab & NCT03484819 & 2 & Recruiting & 106 & $\begin{array}{l}\text { DLBCL failing or } \\
\text { ineligible for } \\
\text { ASCT }\end{array}$ & - \\
\hline Parsaclisib & PI3KS inhibitor & - & $\begin{array}{l}\text { NCT02998476 } \\
\text { (CITA- } \\
\text { DEL-202) }\end{array}$ & 2 & $\begin{array}{l}\text { Active, not } \\
\text { recruiting }\end{array}$ & 60 & $r / r D L B C L$ & [109] \\
\hline Parsaclisib & PI3Kס inhibitor & $\mathrm{R}-\mathrm{CHOP}$ & NCT04323956 & $1 / 1 b$ & $\begin{array}{l}\text { Not yet recruit- } \\
\text { ing }\end{array}$ & 44 & $\begin{array}{c}\text { Newly diagnosed, } \\
\text { high-risk DLBCL }\end{array}$ & - \\
\hline Parsaclisib & PI3K inhibitor & $\begin{array}{l}\text { Rituximab, } \\
\text { bendamus- } \\
\text { tine/ibrutinib }\end{array}$ & NCT03424122 & 1 & Recruiting & 81 & $\mathrm{r} / \mathrm{rNHL}$ & - \\
\hline BR101801 & $\begin{array}{l}\text { PI3K } \delta \text { and } \\
\text { DNA-PK dual } \\
\text { inhibitor }\end{array}$ & - & NCT04018248 & 1 & $\begin{array}{l}\text { Not yet recruit- } \\
\text { ing }\end{array}$ & 90 & $\begin{array}{l}\text { Advanced lym- } \\
\text { phomas }\end{array}$ & - \\
\hline $\begin{array}{l}\text { Umbralisib } \\
\text { (TGR-1202) }\end{array}$ & $\begin{array}{l}\text { PI3K } \delta \text { and CK1 } \\
\text { dual inhibitor }\end{array}$ & $\begin{array}{l}\text { Ublituximab, } \\
\text { bendamus- } \\
\text { tine }\end{array}$ & $\begin{array}{r}\text { NCT02793583 } \\
\text { (UNITY-NHL) }\end{array}$ & $2 / 3$ & Recruiting & 900 & $\begin{array}{l}\text { Previously treated } \\
\mathrm{NHL}\end{array}$ & - \\
\hline Everolimus & $\begin{array}{l}\text { mTORC1 inhibi- } \\
\text { tor }\end{array}$ & Lenalidomide & NCT01075321 & $1 / 2$ & $\begin{array}{l}\text { Active, not } \\
\text { recruiting }\end{array}$ & 58 & $r / r N H L$ or HL & - \\
\hline Temsirolimus & $\begin{array}{l}\text { mTORC1 inhibi- } \\
\text { tor }\end{array}$ & $\begin{array}{l}\text { Rituximab, } \\
\text { DHAP }\end{array}$ & NCT01653067 & 2 & Recruiting & 88 & $\mathrm{r} / \mathrm{rDLBCL}$ & - \\
\hline Venetoclax & BCL2 inhibitor & - & NCT01328626 & 1 & Recruiting & 222 & $r / r C L L$ and $N H L$ & [101] \\
\hline Venetoclax & BCL2 inhibitor & $\begin{array}{l}\text { Lenalidomide, } \\
\text { obinutu- } \\
\text { zumab }\end{array}$ & NCT02992522 & 1 & Suspended & 60 & $\mathrm{r} / \mathrm{rNHL}$ & - \\
\hline Venetoclax & BCL2 inhibitor & $\begin{array}{l}\text { Atezolizumab, } \\
\text { obinutu- } \\
\text { zumab }\end{array}$ & NCT03276468 & 2 & Recruiting & 138 & $\begin{array}{l}r / r \text { DLBCL and } \\
\text { indolent NHL }\end{array}$ & - \\
\hline Venetoclax & BCL2 inhibitor & RICE & NCT03064867 & $1 / 2$ & Recruiting & 64 & $r / r D L B C L$ & - \\
\hline Venetoclax & BCL2 inhibitor & DA-EPOCH-R & NCT03036904 & 1 & $\begin{array}{l}\text { Active, not } \\
\text { recruiting }\end{array}$ & 34 & $\begin{array}{l}\text { DLBCL and } \\
\text { HGBCL }\end{array}$ & - \\
\hline Venetoclax & BCL2 inhibitor & $\begin{array}{l}\text { Obinutuzumab, } \\
\text { rituximab, } \\
\text { polatuzumab } \\
\text { vedotin }\end{array}$ & NCT02611323 & 1 & Recruiting & 134 & $\begin{array}{l}\text { r/r DLBCL and } \\
\text { follicular lym- } \\
\text { phoma }\end{array}$ & - \\
\hline Venetoclax & BCL2 inhibitor & Obinutuzumab & NCT02987400 & 2 & Recruiting & 21 & $\mathrm{r} / \mathrm{rDLBCL}$ & - \\
\hline Entospletinib & $\begin{array}{l}\text { Spleen tyrosine } \\
\text { kinase inhibi- } \\
\text { tor }\end{array}$ & $\mathrm{R}-\mathrm{CHOP}$ & NCT03225924 & $1 / 2$ & $\begin{array}{l}\text { Active, not } \\
\text { recruiting }\end{array}$ & 25 & $\begin{array}{r}\text { Newly diagnosed } \\
\text { DLBCL aalPI } \geq 1\end{array}$ & - \\
\hline Ibrutinib & BTK inhibitor & $\begin{array}{l}\text { ABT-199, rituxi- } \\
\text { mab }\end{array}$ & NCT03136497 & 1 & Recruiting & 30 & $\mathrm{r} / \mathrm{rDLBCL}$ & - \\
\hline Ibrutinib & BTK inhibitor & $\begin{array}{l}\text { ABT-199, pred- } \\
\text { nisone, obi- } \\
\text { nutuzumab, } \\
\text { lenalidomide }\end{array}$ & NCT03223610 & $1 \mathrm{~b} / 2$ & Recruiting & 130 & $\begin{array}{l}\text { CD20 positive B } \\
\text { cell lymphoma }\end{array}$ & - \\
\hline Ibrutinib & BTK inhibitor & $\begin{array}{l}\text { Loncastuximab } \\
\text { tesirine }\end{array}$ & NCT03684694 & $1 / 2$ & Recruiting & 161 & $\begin{array}{l}\text { Advanced DLBCL, } \\
\text { mantle cell } \\
\text { lymphoma }\end{array}$ & - \\
\hline Ibrutinib & BTK inhibitor & $\begin{array}{l}\text { Lenalidomide, } \\
\text { rituximab }\end{array}$ & NCT02077166 & $1 / 2$ & $\begin{array}{l}\text { Active, not } \\
\text { recruiting }\end{array}$ & 129 & $\begin{array}{l}r / r \text { non-GCB } \\
\text { DLBCL }\end{array}$ & [119] \\
\hline Ibrutinib & BTK inhibitor & R-ICE & NCT02955628 & 2 & Recruiting & 34 & $\begin{array}{l}\text { Pre-transplant r/r } \\
\text { DLBCL }\end{array}$ & - \\
\hline Ibrutinib & BTK inhibitor & Buparlisib & NCT02756247 & 1 & $\begin{array}{l}\text { Active, not } \\
\text { recruiting }\end{array}$ & 37 & $\begin{array}{l}r / r \text { DLBCL, FL, } \\
\text { mantle cell } \\
\text { lymphoma }\end{array}$ & [95] \\
\hline
\end{tabular}


Table 4 (continued)

\begin{tabular}{|c|c|c|c|c|c|c|c|c|}
\hline Agent & Agent type & $\begin{array}{l}\text { Combined } \\
\text { agent }\end{array}$ & Study & Study phase & $\begin{array}{l}\text { Recruitment } \\
\text { status }\end{array}$ & $\begin{array}{l}\text { Enrollment } \\
\text { (estimated/ } \\
\text { actual) }\end{array}$ & Indication & $\begin{array}{l}\text { Results } \\
\text { for DLBCL }\end{array}$ \\
\hline ARQ-531 & BTK inhibitor & - & NCT03162536 & $1 / 2$ & Recruiting & 146 & $\begin{array}{l}\text { Selected } \\
\text { hematologic } \\
\text { malignancies }\end{array}$ & - \\
\hline LOXO-305 & BTK inhibitor & $\begin{array}{l}\text { Venetoclax, } \\
\text { R-CHOP }\end{array}$ & NCT03740529 & $1 / 2$ & Recruiting & 403 & CLL/SLL, NHL & - \\
\hline DTRMWXHS-12 & BTK inhibitor & $\begin{array}{l}\text { Everolimus, } \\
\text { pomalido- } \\
\text { mide }\end{array}$ & NCT04305444 & 2 & Recruiting & 120 & $r / r C L L, N H L$ & - \\
\hline Acalabrutinib & BTK inhibitor & - & NCT02112526 & 1 & Recruiting & 21 & $\mathrm{r} / \mathrm{r} A B C D L B C L$ & [96] \\
\hline Acalabrutinib & BTK inhibitor & RICE & NCT03736616 & 2 & Recruiting & 47 & $\begin{array}{l}\text { DLBCL after first- } \\
\text { line failure }\end{array}$ & - \\
\hline Acalabrutinib & BTK inhibitor & DA-EPOCH & NCT04002947 & 2 & Recruiting & 112 & untreated DLBCL & - \\
\hline Acalabrutinib & BTK inhibitor & $\mathrm{R}-\mathrm{CHOP}$ & NCT03571308 & $1 / 2$ & Recruiting & 39 & untreated DLBCL & - \\
\hline Acalabrutinib & BTK inhibitor & $\begin{array}{l}\text { pembroli- } \\
\text { zumab }\end{array}$ & NCT02362035 & $1 \mathrm{~b} / 2$ & $\begin{array}{l}\text { Active, not } \\
\text { recruiting }\end{array}$ & 161 & $\begin{array}{c}r / r \text { hematologic } \\
\text { malignancies }\end{array}$ & [97] \\
\hline Enzastaurin & PKC $\beta$ inhibitor & $\mathrm{R}-\mathrm{CHOP}$ & NCT03263026 & 3 & Recruiting & 235 & $\begin{array}{l}\text { untreated DGM1- } \\
\text { positive DLBCL, } \\
\mid \mathrm{PI} \geq 3\end{array}$ & - \\
\hline Lenalidomide & $\begin{array}{l}\text { Immunomodu- } \\
\text { latory agent }\end{array}$ & - & $\begin{array}{l}\text { NCT04150328 } \\
\text { (RE-MIND) }\end{array}$ & 2 & Recruiting & 500 & $\mathrm{r} / \mathrm{rDLBCL}$ & [69] \\
\hline Lenalidomide & $\begin{array}{l}\text { Immunomodu- } \\
\text { latory agent }\end{array}$ & MOR208 & $\begin{array}{l}\text { NCT02399085 } \\
\text { (L-MIND) }\end{array}$ & 2 & $\begin{array}{l}\text { Active, not } \\
\text { recruiting }\end{array}$ & 81 & $\begin{array}{l}\text { r/r DLBCL, non- } \\
\text { transplant } \\
\text { eligible }\end{array}$ & [69] \\
\hline Lenalidomide & $\begin{array}{l}\text { Immunomodu- } \\
\text { latory agent }\end{array}$ & $\mathrm{R}-\mathrm{CHOP}$ & NCT00670358 & $1 / 2$ & Recruiting & 47 & Untreated DLBCL & [34] \\
\hline Lenalidomide & $\begin{array}{l}\text { Immunomodu- } \\
\text { latory agent }\end{array}$ & R-CHOP & NCT00907348 & 2 & Unknown & 49 & $\begin{array}{l}\text { Elderly untreated } \\
\qquad \mathrm{DLBCL}, \mid \mathrm{PI} \geq 2\end{array}$ & [34] \\
\hline Lenalidomide & $\begin{array}{l}\text { Immunomodu- } \\
\text { latory agent }\end{array}$ & R-CHOP & NCT01856192 & 2 & $\begin{array}{l}\text { Active, not } \\
\text { recruiting }\end{array}$ & 345 & $\begin{array}{l}\text { Untreated stage } \\
\text { II-IV DLBCL }\end{array}$ & - \\
\hline Lenalidomide & $\begin{array}{l}\text { Immunomodu- } \\
\text { latory agent }\end{array}$ & $\mathrm{R}-\mathrm{CHOP}$ & NCT02285062 & 3 & $\begin{array}{l}\text { Active, not } \\
\text { recruiting }\end{array}$ & 570 & $\begin{array}{l}\text { Untreated ABC } \\
\text { DLBCL }\end{array}$ & {$[36]$} \\
\hline Lenalidomide & $\begin{array}{l}\text { Immunomodu- } \\
\text { latory agent }\end{array}$ & $\begin{array}{l}\text { miniCHOP, sub- } \\
\text { cutaneous } \\
\text { rituximab }\end{array}$ & $\begin{array}{l}\text { NCT02128061 } \\
\text { (SENIOR) }\end{array}$ & 3 & $\begin{array}{l}\text { active, not } \\
\text { recruiting }\end{array}$ & 250 & $\begin{array}{l}\text { Untreated } \\
\text { CD20 + DLBCL, } \\
\text { aged over } \\
80 \text { years }\end{array}$ & [37] \\
\hline Lenalidomide & $\begin{array}{l}\text { Immunomodu- } \\
\text { latory agent }\end{array}$ & $\begin{array}{c}\text { Rituximab, } \\
\text { ibrutinib }\end{array}$ & NCT02636322 & 2 & $\begin{array}{l}\text { Active, not } \\
\text { recruiting }\end{array}$ & 60 & $\begin{array}{l}\text { Newly diagnosed } \\
\text { non-GCB } \\
\text { DLBCL }\end{array}$ & [120] \\
\hline Itacitinib & JAK1 inhibitor & Parsaclisib & $\begin{array}{l}\text { NCT02018861 } \\
\text { (CITA- } \\
\text { DEL-101) }\end{array}$ & $1 / 2$ & $\begin{array}{l}\text { Active, not } \\
\text { recruiting }\end{array}$ & 88 & $\begin{array}{l}\text { r/r B cell malig- } \\
\text { nancies }\end{array}$ & [122] \\
\hline Itacitinib & JAK1 inhibitor & Ibrutinib & NCT02760485 & $1 / 2$ & $\begin{array}{l}\text { Active, not } \\
\text { recruiting }\end{array}$ & 33 & $\mathrm{r} / \mathrm{r} \mathrm{DLBCL}$ & - \\
\hline Ruxolitinib & $\begin{array}{l}\text { JAK1/2 inhibi- } \\
\text { tor }\end{array}$ & - & NCT01431209 & 2 & $\begin{array}{l}\text { Active, not } \\
\text { recruiting }\end{array}$ & 71 & $\begin{array}{l}r / r \text { NHL failing or } \\
\text { ineligible for } \\
\text { SCT }\end{array}$ & [123] \\
\hline Valemetostat & $\begin{array}{l}\mathrm{EZH1/2} \mathrm{dual} \\
\text { inhibitor }\end{array}$ & - & NCT02732275 & 1 & Recruiting & 70 & $\begin{array}{l}\text { Adults with } \\
\text { advanced NHL }\end{array}$ & - \\
\hline Tazemetostat & EZH2 inhibitor & - & NCT01897571 & $1 / 2$ & $\begin{array}{l}\text { Active, not } \\
\text { recruiting }\end{array}$ & 420 & $\begin{array}{l}\text { NHL and } \\
\text { advanced solid } \\
\text { tumors }\end{array}$ & [130] \\
\hline Tazemetostat & EZH2 inhibitor & $\mathrm{R}-\mathrm{CHOP}$ & NCT02889523 & $1 / 2$ & Suspended & 133 & $\begin{array}{l}\text { Untreated high- } \\
\text { risk DLBCL }\end{array}$ & [132] \\
\hline Tazemetostat & EZH2 inhibitor & - & NCT03456726 & 2 & $\begin{array}{l}\text { Active, not } \\
\text { recruiting }\end{array}$ & 21 & $\begin{array}{c}\text { r/r NHL, EZH2 } \\
\text { mutation }\end{array}$ & - \\
\hline
\end{tabular}


Table 4 (continued)

\begin{tabular}{|c|c|c|c|c|c|c|c|c|}
\hline Agent & Agent type & $\begin{array}{l}\text { Combined } \\
\text { agent }\end{array}$ & Study & Study phase & $\begin{array}{l}\text { Recruitment } \\
\text { status }\end{array}$ & $\begin{array}{l}\text { Enrollment } \\
\text { (estimated/ } \\
\text { actual) }\end{array}$ & Indication & $\begin{array}{l}\text { Results } \\
\text { for DLBCL }\end{array}$ \\
\hline Tazemetostat & EZH2 inhibitor & - & NCT02875548 & 2 & Recruiting & 300 & $\begin{array}{l}\text { Patients with } \\
\text { antecedent } \\
\text { tazemetostat } \\
\text { study }\end{array}$ & - \\
\hline Panobinostat & $\mathrm{HDACi}$ & - & NCT01261247 & 2 & $\begin{array}{l}\text { Active, not } \\
\text { recruiting }\end{array}$ & 41 & $r / r N H L$ & - \\
\hline Vorinostat & $\mathrm{HDACi}$ & $\mathrm{R}-\mathrm{CHOP}$ & NCT00972478 & $1 / 2$ & $\begin{array}{l}\text { Active, not } \\
\text { recruiting }\end{array}$ & 83 & $\begin{array}{l}\text { Untreated stage } \\
2-4 \mathrm{DLBCL}\end{array}$ & - \\
\hline Chidamide & $\mathrm{HDACi}$ & - & NCT03201471 & 2 & Recruiting & 39 & High-risk DLBCL & - \\
\hline Romidepsin & $\mathrm{HDACi}$ & 5-Azacitidine & NCT01998035 & $1 / 2$ & $\begin{array}{l}\text { Active, not } \\
\text { recruiting }\end{array}$ & 52 & $r / r N H L$ & - \\
\hline Selinexor & XPO1 inhibitor & Venetoclax & NCT03955783 & 1 & Suspended & 78 & $\begin{array}{l}\text { r/r high-risk } \\
\text { DLBCL, leuke- } \\
\text { mia }\end{array}$ & [143] \\
\hline Selinexor & XPO1 inhibitor & $\mathrm{R}-\mathrm{CHOP}$ & NCT03147885 & $1 b / 2$ & Recruiting & 44 & $\mathrm{NHL}$ & - \\
\hline Selinexor & XPO1 inhibitor & RICE & NCT02471911 & 1 & $\begin{array}{l}\text { Active, not } \\
\text { recruiting }\end{array}$ & 23 & $\begin{array}{l}\text { r/r aggressive B } \\
\text { cell lymphoma }\end{array}$ & - \\
\hline
\end{tabular}

NHL non-Hodgkin lymphoma, $R$-CHOP rituximab, cyclophosphamide, doxorubicin, vincristine, and prednisone, $D L B C L$ diffuse large $B$ cell lymphoma, $r / r$ relapsed/ refractory, EZH enhancer of zeste homolog, CLL chronic lymphocytic leukemia, G-CHOP obinutuzumab, cyclophosphamide, doxorubicin, vincristine, and prednisone, RICE rituximab, ifosfamide, carboplatin, and etoposide, DA-EPOCH-R dose-adjusted etoposide, prednisone, vincristine, cyclophosphamide, doxorubicin, and rituximab, $H G B C L$ high-grade B cell lymphoma, HL Hodgkin lymphoma, GCB germinal center B cell like, PI3K phosphatidylinositol-3-kinase, aalPI age-adjusted international prognosis index, BTK Bruton's tyrosine kinase inhibitor, SLL small lymphocytic lymphoma, $P K C \beta$ protein kinase C $\beta, P M B C L$ primary mediastinal B cell lymphoma, JAK janus kinase, ASCT autologous stem cell transplantation, HDACi histone deacetylase inhibitors

${ }^{a}$ If the study results are published, the reference number will be given

Ibrutinib, the first approved BTK inhibitor, has shown activity in the $r / r$ setting of ABC-DLBCLs, especially those with concurrent CD79b and MYD88 mutation [92]. Combined ibrutinib with R-ICE (rituximab, ifosfamide, carboplatin, and etoposide) resulted in an ORR of $90 \%$ in $\mathrm{r} / \mathrm{r}$ DLBCL and a CR rate of $100 \%$ in patients with nonGCB subtype [93]. Nevertheless, ibrutinib with R-CHOP did not benefit the overall patients with untreated nonGCB DLBCL in a randomized, placebo-controlled, phase III PHEONIX study [6], but addition of ibrutinib to R-CHOP benefited younger patients of DLBCL, especially those with both c-MYC and BCL-2 overexpression. Since primary resistance to BTK inhibition in DLBCL was associated with BCR signaling activation, ibrutinib combination therapies with venetoclax are now under active clinical investigation [94]. Also, the combination of BTK and PI3K inhibition with ibrutinib and buparlisib was tested, reporting a CR rate of $23 \%$ in 13 patients with $\mathrm{r} / \mathrm{r}$ DLBCL [95]. Besides, acalabrutinib monotherapy showed promising activities among 21 patients with $\mathrm{r} / \mathrm{r}$ DLBCL, inducing CRs in 5 patients (including $1 \mathrm{GCB}$ DLBCL) [96]. Furthermore, BTK inhibition may synergize with immunotherapy, since acalabrutinib in combination with pembrolizumab resulted in ORRs of $27 \%$ in GCB $(n=30)$ and $26 \%$ in non-GCB r/r DLBCL $(n=31)$, with a median DoR of 6.9 months [97].
In a randomized phase II trial, frontline $\mathrm{PKC} \beta$ inhibitor enzastaurin plus R-CHOP showed improved median PFS compared with R-CHOP alone (36 vs. 23 months, respectively), especially for high-risk patients [98]. A new phase III ENGINE study is ongoing to test enzastaurin with $\mathrm{R}-\mathrm{CHOP}$ in high-risk DLBCL patients positive for DGM1, a genetic biomarker signifying responses to enzastaurin treatment [99].

\section{$B C L-2$ inhibition}

In DLBCL, B cell lymphoma-2 (BCL-2) overexpression maintained tumor viability through apoptosis inhibition and mediated molecular mechanisms underlying $\mathrm{R}-\mathrm{CHOP}$ resistance [100]. Constitutive overexpression of BCL-2 was detected in both subtypes of DLBCL through distinct mechanisms: chromosomal translocations in GCB DLBCL and NF- $\mathrm{kB}$ signaling activation in ABC DLBCL. BCL2 translocation was detected in $28.0 \%$ of GCB and $0.7 \%$ of ABC DLBCL [85]. Therefore, BCL-2 inhibition is most likely to be effective in the cluster 5 with extranodal $A B C$ and cluster 3 with GCB, which exhibited BCL-2 overexpression plus frequent mutations of CD79B and MYD88 ${ }^{\mathrm{L} 265 \mathrm{P}}$ (Fig. 4), or frequent mutations in epigenetic enzymes (e.g., KMT2D, CREBBP, and EZH2), BCL-2 and PTEN, respectively, as defined by Chapuy et al. [86]. 
The selective, orally bioavailable BCL-2 inhibitor venetoclax (ABT-199) was tested in a multitude of phase I and II studies. The first-in-human phase I trial of venetoclax reported an ORR of $18 \%$ in 34 patients with $\mathrm{r} / \mathrm{r}$ DLBCL, with an estimated median PFS of 1 month [101]. The most common grade 3 and 4 hematologic adverse events at target doses from 200 to $1200 \mathrm{mg}$ for all NHLs were anemia (15\%), neutropenia (11\%), and thrombocytopenia (9\%) [101]. First-line venetoclax was tested in 56 patients with NHL in combination with R-/G-CHOP, including 18 patients with DLBCL. ORR was reported to be $87.5 \%$ for all NHLs, and CR rate was $79.2 \%$ and $78.1 \%$ in venetoclax with R-CHOP and G-CHOP, respectively [102]. A retrospective cohort study evaluated the off-label use of salvage venetoclax with concomitant therapy in 34 patients with NHL, including 13 DLBCL. With median venetoclax dosed at $400 \mathrm{mg}$, the ORR was achieved at $26 \%$ and CR at $3 \%$ in the entire cohort. The observed median PFS for the DLBCL cohort was 2 months [103]. Moreover, preclinical study showed synergistic activity between the BCL-2 inhibitor navitoclax (ABT-263) and bendamustine [104], but the phase II clinical study on navitoclax plus bendamustine and rituximab in $\mathrm{r} / \mathrm{r}$ DLBCL was withdrawn due to non-safety-related reasons (NCT01423539). Thus, reliable biomarkers need to be extensively investigated to guide the use of BCR inhibition in DLBCL due to the currently modest efficacy.

\section{VEGFR inhibition}

Similar to the fate of bortezomib or ibrutinib in first-line treatment setting of DLBCL, bevacizumab (Avastin), a humanized monoclonal antibody targeting VEGF-A, did not show benefits when added to R-CHOP in patients with newly diagnosed DLBCL [105]. However, this study did not prevent VEGFR from being an effective target in $r / r$ DLBCL. Apatinib is an orally administered novel tyrosine kinase inhibitor targeting vascular endothelial growth factor receptor-2 (VEGFR-2), which involves in lymphomagenesis. Home administration of apatinib with regular outpatient follow-up produced encouraging antitumor effects in $\mathrm{r} / \mathrm{r}$ DLBCL in an open-label, singlearm, prospective study [106]. ORR of $43.8 \%$ and a disease control rate of $71.9 \%$ were reported, with a median DoR of 5.0 (95\% CI 3.5-6.5) months $(n=32)$. The most common toxicities of any grade were hypertension $(62.5 \%)$, leukopenia (40.6\%), and hand-foot syndrome (40.6\%) [106]. The relatively high response rate attained by apatinib deserves future investigation of drug combination strategies.

\section{PI3K/Akt/mTOR inhibition}

PI3K/Akt/mTOR (mammalian target of rapamycin) signaling pathway is involved in the constitutive activation of BCR signaling and cell adhesion-mediated drug resistance within tumor microenvironment [107]. Current clinical results of $\mathrm{PI} 3 \mathrm{~K} / \mathrm{Akt} / \mathrm{mTOR}$ signaling inhibition (Fig. 4) showed modest responses in $\mathrm{r} / \mathrm{r}$ DLBCL. The efficacy and safety of $\mathrm{PI} 3 \mathrm{~K} \alpha / \delta$ inhibitor copanlisib (Aliqopa; BAY80-6946) were tested in a phase 2 trial, in which patients with ABC $\mathrm{r} / \mathrm{r}$ DLBCL had an ORR of $13.3 \%$, whereas an ORR of $31.6 \%$ was achieved in patients with GCB subtype. The PFS was 1.8 and 4.3 months in $\mathrm{ABC}$ and GCB subgroups, respectively. Treatment-emergent adverse events mostly reported were hypertension (40.3\%), diarrhea (37.3\%), and hyperglycemia (32.8\%) [108]. Parsaclisib (INCB050465), a selective next-generation oral PI3K $\delta$ inhibitor, showed single-agent efficacy for $\mathrm{r} / \mathrm{r}$ DLBCL in a phase 2 trial. ORR was $20 \%$ and $25.5 \%$, respectively, for patients who previously received BTK inhibitors or not [109].

Everolimus (RAD001) and temsirolimus (CCI-779) are rapamycin analogues directing against mTORC1. Single-agent everolimus got an ORR of $30 \%$ and DoR of 5.7 months in a phase 2 study, which enrolled $77 \mathrm{r} / \mathrm{r}$ DLBCL patients after a median of 3 prior therapies. The regimen was well tolerated, and the most common grade 3 and 4 adverse events included thrombocytopenia (38\%), neutropenia (18\%), and anemia (14\%) [110]. Similar outcomes were reported with single-agent temsirolimus in the $\mathrm{r} / \mathrm{r}$ DLBCL cohort of a phase 2 trial, in which the ORR was $28 \%$ with a DoR of 2.4 months [111]. When combined with rituximab, everolimus produced an ORR rate of $38 \%(9 / 24)$ and median DoR of 8.1 months in heavily pretreated DLBCL [112]. Though the phase 3 PILLAR-2 trial reported no significantly improved disease-free survival (DFS) with 1-year everolimus maintenance therapy in poor-risk patients with newly diagnosed DLBCL (hazard ratio, 0.92; 2-year DFS, 77.8\% vs. $77.0 \%$, for everolimus vs. placebo, respectively) [113], combined everolimus with R-CHOP-21 produced high EFS12 and EFS24 rates of $100 \%$ in the phase 1 Alliance study, in which $96 \%$ of newly diagnosed DLBCL patients achieved response [114].

\section{NF-kB pathway inhibition}

As downstream effector of chronic-active BCR signaling, sustained activity of NF- $\mathrm{KB}$ signaling exerts a prominent survival feature for $A B C$ DLBCL. Downstream expressions of cyclinD2, CCR7, IRF4, FLIP, NFKBIA, and BCL-2 were highly expressed in many of the $A B C$ DLBCLs rather than GCB DLBCLs [115]. The proteasome inhibitor bortezomib (Velcade) proves to inhibit NF-kB pathway (Fig. 4) and showed activity in $\mathrm{r} / \mathrm{r}$ ABCDLBCL [116]. However, addition of bortezomib to $\mathrm{R}-\mathrm{CHOP}$ or replacement of vincristine by bortezomib 
(VR-CAP) did not improve both response rates and long-term survival outcomes in patients with non-GCB DLBCL [4]. It has been demonstrated that functional PRDM1 is required for mantle cell lymphoma response to bortezomib [117], while loss of PRDM1 was found in more than half of the patients with ABC-DLBCL, which may hinder the apoptosis induced by bortezomib [118]. Thus, the expression status of PRDM1 should be assessed before implement of bortezomib in treatment of DLBCL.

Lenalidomide can also exert direct tumor toxicities via binding to cereblon to inhibit downstream NF- $\mathrm{KB}$ signaling [33]. As aforementioned, lenalidomide has been shown to provide benefits for $\mathrm{r} / \mathrm{r}$ ABC-DLBCL $[39,40]$, as well as elderly patients when used as maintenance therapy [35]. Moreover, promising and durable activity was observed for triplet ibrutinib, rituximab, and 10-25 mg lenalidomide (IR2 regimen) in $\mathrm{r} / \mathrm{r}$ DLBCL, particularly in non-GCB DLBCL (ORR: 65\% vs. 29\%; median DoR: 15.9 vs. 8.8 months, for non-GCB vs. GCB, respectively) [119]. In SMART START trial, the same triplet combination with $25 \mathrm{mg}$ lenalidomide as a leadingin regimen in the first-line setting for non-GCB DLBCL gave impressive results, with an ORR and CR rate of $86 \%$ and $36 \%$, respectively, after two cycles of IR2 treatment [120]. Prolongation of IR2 use and reduction in chemotherapy cycles are needed in future exploration, especially for those relatively unfit patients.

\section{JAK/STAT3 inhibition}

STAT3 expression was detected in 37\% of DLBCL and $54 \%$ of ABC DLBCL and signified poor survival especially for the $A B C$ subtype when treated with $\mathrm{R}-\mathrm{CHOP}$ [121]. Conceivably, activation of the JAK/STAT3 signaling pathway in $A B C$ DLBCL indicates promising therapeutic targets, including JAK, STAT3, and IL-10 receptor (Fig. 4). JAK inhibitors, such as the JAK1 inhibitor itacitinib (INCB039110) and JAK1/2 inhibitor ruxolitinib, have been investigated for the treatment of $r / r$ DLBCL, with phase I/II results already reported. Itacitinib $300 \mathrm{mg}$ once daily was tested in the CITADEL-101 study combined with parsaclisib, but all 6 patients with $\mathrm{r} / \mathrm{r}$ DLBCL had best overall response of progressive (metabolic) disease [122]. Ruxolitinib produced a median PFS of 1.8 months and OS of 5 months in $\mathrm{r} / \mathrm{r}$ DLBCL who were ineligible for, or failed SCT $(n=32)$ [123]. According to results from a phase Ib trial, AZD9150, a next-generation antisense oligonucleotide inhibitor of STAT3 mRNA showed efficacy in patients with $r / r$ DLBCL [124]. Two in 27 patients achieved CRs (1 each at $2 \mathrm{mg} / \mathrm{kg}$ and $3 \mathrm{mg} / \mathrm{kg}$ dose levels), and 2 achieved PRs, announcing a median DoR of 10.7 months [124]. From the data shown above, JAK/STAT3 inhibition seems unworthy of further investigation in DLBCL, unless predictive biomarkers are available to guide treatment with this strategy.

\section{Selective inhibitors of nuclear export}

The selective inhibitors of nuclear transport (SINE) have been developed as a novel class of anti-DLBCL agents [125]. The most well-known SINE inhibitor is selinexor (KPT-330, XPOVIO), which is a first-in-class, investigational oral therapeutic that selectively blocks exportin 1 (XPO1) and leads to reductions in $M Y C$ and BCL2 oncogenes (Fig. 4) [126]. Selinexor has demonstrated notable efficacy in the open-label SADAL phase IIb study [126] and received final approval from FDA for the treatment of patients with $\mathrm{r} / \mathrm{r}$ DLBCL after at least 2 lines of systemic therapy in June 2020. Among this SADAL population of 127 patients, selinexor produced an ORR of $28 \%$ and CR of $12 \%$, with a median DoR of 9.3 months. In the cohort with prior SCT, the greatest benefits were observed (ORR: 44\%; median PFS: 5.9 months). Most common grade 3-4 adverse events were thrombocytopenia, neutropenia, and anemia [126]. It is worth exploring XPO1 inhibitor-based combinational therapy in $\mathrm{r} / \mathrm{r}$ setting after $\mathrm{R}-\mathrm{CHOP}$ failure according to the above impressive findings, but special attention should be paid to the severe adverse events when using selinexor.

\section{Epigenetic-modifying drugs}

Epigenetic modulation, such as DNA methylation and histone deacetylation, involves in tumorigenesis among lots of solid tumors and hematologic malignancies. Increasing data have demonstrated both direct antitumor activity and enhancement of the function of immune cells, making it an appealing strategy in the treatment of DLBCL (Fig. 4).

\section{Histone deacetylase inhibitors}

Histone deacetylase inhibitors (HDACis), including panobinostat, vorinostat (Zolinza, SAHA), chidamide (HBI8000), and romidepsin (FR901228), are used as novel, off-label anticancer epigenetic therapies for DLBCL. At $30 \mathrm{mg}$ three times weekly, panobinostat resulted in an ORR of $28 \%$ in patients with $\mathrm{r} / \mathrm{r}$ DLBCL in a phase II trial, with a median DoR of 14.5 months [127]. Although the response rate was not impressive when using as monotherapy, those who got remission enjoyed a relatively long duration of remission. Thus, useful biomarkers to predict patients who are deemed to benefit from panobinostat are urgently needed. Rituximab combination did not increase responses, while MEF2B mutations and circulation tumor DNA (ctDNA) reduction were predictors of early responses [127]. Mondello et al. demonstrated in vitro that panobinostat induced mutations in the STAT3 binding site to downregulate mutant-MYD88 
transcription, inhibited NF- $\mathrm{kB}$ activation, and promoted ibrutinib efficacy in ABC DLBCL cells [128]. This provides foundation for the combination therapy with ibrutinib and panobinostat in ABC DLBCL, especially for the cluster 5 defined by Chapuy et al. [86]. Because HDACi exhibited immunomodulatory effects and could synergize with immune checkpoint inhibitors to produce enhanced antitumor activity, vorinostat and pembrolizumab demonstrated an ORR of $56 \%$ and a CR of $33 \%$ in $\mathrm{r} / \mathrm{r} \operatorname{DLBCL}(n=9)$ [129].

\section{EZH2 inhibition}

Enhancer of zeste homolog 2 (EZH2) is a histone methyltransferase, repressing nuclear transcription by trimethylating histone $\mathrm{H} 3$ lysine $27.22 .0 \%$ of GCB and $1.7 \%$ of $A B C$ DLBCL exhibited gain-of-function mutations in $\mathrm{EZH} 2$ that mediated epigenetic modification and led to tumor survival [85]. Tazemetostat (EPZ-6438) is an oral, first-in-class, selective small-molecule EZH2 inhibitor, which has been approved by FDA to treat adult patients with relapsed or refractory follicular lymphoma (FL) whose tumors are positive for an EZH2 mutation and who have received at least 2 prior systemic therapies, or those who have no optimal alternative treatment options. Single-agent efficacy of tazemetostat in NHL and advanced solid tumors was studied in a first-in-human phase I/ II trial [130, 131]. Interim results from the phase II trial showed an ORR rate of $40 \%$ in DLBCL with EZH2 mutations and 18\% in DLBCL without mutations [131]. Other trials of tazemetostat in DLBCL indications include a phase I/II study evaluating tazemetostat in combination with R-CHOP for high-risk newly diagnosed DLBCL patients. Phase Ib of this study determined $800 \mathrm{mg}$ as the recommended phase 2 dose [132]. Preliminary efficacy data were encouraging with a metabolic $\mathrm{CR}$ rate of $76.5 \%$ (13/17), and the duration of CR was 2-14 months [132]. Long-term safety and overall survival of patients treated with tazemetostat will be evaluated in the rollover study TRuST (NCT02875548). Other EZH2 inhibitors, such as CPI-1205 [133] and GSK2816126 [134], have also shown promising anti-DLBCL activity and tolerable safety profiles in preliminary phase 1 studies. MAK683, the embryonic ectoderm development protein (EED) inhibitor, can induce reduced tumor cell proliferation in EZH2 mutated cells through binding to EED to block the interaction between EED and EZH2. A phase 1/2 study is undergoing to evaluate the efficacy of MAK683 in a variety of malignancies, including DLBCL (NCT02900651). Further, the EZH1 and EZH2 dual inhibitor valemetostat (DS-3201b) had antitumor activities in both ABC and GCB DLBCL cells in vitro, which is now under investigation in a phase I trial for advanced NHL including DLBCL [135].

\section{Bromodomain inhibitors}

Bromodomain inhibitors are a novel generation of small -molecule inhibitors targeting BET (bromodomain and extra terminal) proteins, which normally trigger gene transcription via complicated mechanisms. Some oncogenes are under epigenetic modulations by BET, such as c-MYC [136]. Thus, bromodomain inhibitors may present with antitumor efficacy by suppressing the expression of those oncogenes. OTX015 (MK8628), a selective inhibitor of BET, showed prominent anti-lymphoma activity in vitro [137]. Preclinical investigations demonstrated that OTX015 had various targets, including NF-KB/TLR/ JAK/STAT signaling pathways, MYC-related genes, and genes that regulate cell cycle [137]. In a phase I trial, 37 patients (including 18 DLBCL patients) were treated with OTX015 monotherapy, and unsatisfactory efficacy was observed with one CR and one PR in patients with heavily pretreated DLBCL. The prognosis for patients with $\mathrm{r} / \mathrm{r}$ double-hit lymphoma (concurrent $B C L 2$ and $M Y C$ translocations) is extremely poor without active salvage agents. Based on the results of in vitro study, BET inhibitors alone or in combination with BCL-2 inhibitors may provide therapeutic potential for patients with MYCdependent lymphomas in the future [138].

\section{Conclusion}

Due to the great heterogeneity of DLBCL, one-third of patients will eventually failed R-CHOP treatment, and great challenges exist regarding how to accurately predict outcomes and provide individualized salvage therapies (Fig. 5) [144]. Although several novel molecular subtyping systems have been developed those years, about half of the patients could not be classified into a specific subtype, and there is still a long way to go before implementation of those molecular subtypes in routine clinical practice. From the data shown above, CAR-based cell therapies exhibit the most promising results. Multi-target CAR T cells, combination of different mono-target CAR T cells, CAR T cells combined with ICIs or novel molecular inhibitors, or fourthgeneration CAR $T$ cells with safety switches can further improve both the efficacy and safety profiles in $\mathrm{r} / \mathrm{r}$ DLBCL. Similarly, different target-based BiTEs are also promising due to convenient accessibility. Regarding the small molecular inhibitors or epigenetic modifying drugs, it is impossible to cure DLBCL with monotherapy because no driver gene aberrations have been identified for DLBCL. However, with so many new drugs in the development pipeline, there will be enormous number of drug combination mode, which is extremely difficult to investigate in clinical trials due to limited patient resources. Exploring reliable biomarkers to guide individualized treatment is worth many efforts, 


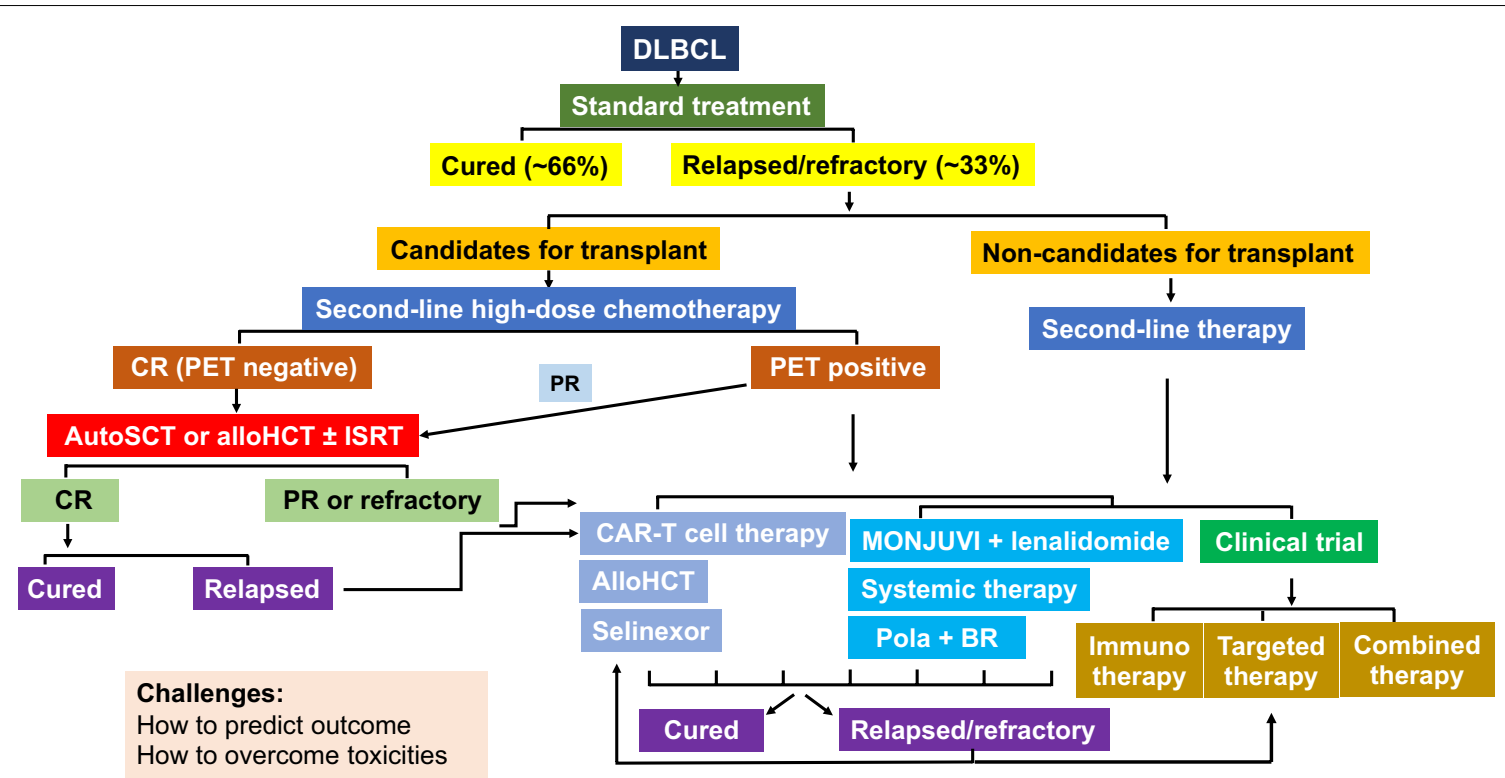

Fig. 5 Recommended treatment for DLBCL. PET positron emission tomography and computed tomography, SCR stem cell rescue, ISRT involved site radiotherapy, CAR chimeric antigen receptor, HCT stem cell transplantation, Pola +BR polatuzumab vedotin combined with bendamustine and rituximab

and screening drugs with potential synergistic effect is helpful to design combinational trials. Moreover, the potential superimposed toxicity profiles should be considered when novel drugs with distinct mechanisms of action are used together, especially for DLBCL where many targets are not specific and off-target effects are inevitable. Meanwhile, unlike cytotoxic drugs, many novel targeted agents or immunotherapies work slowly in patients, and pseudo-progress occurs at some point, which warrants up-to-date response criteria. Finally, though a long way toward the cure of DLBCL, with the guidance of detailed genetic information, the optimal combination of both novel and traditional drugs will emerge to promote precision medicine in patients with DLBCL.

\section{Acknowledgements}

Dr. Zijun Xu-Monette and Dr. Xiaosheng Fang are greatly appreciated for the support of figure construction and critical review of the manuscript.

\section{Authors' contributions}

LW and KHY conceived and designed the study. LW, LRL, and KHY contributed to research performance, provision of study thought, data analysis, manuscript writing and final approval of manuscript. All authors read and approved the final manuscript.

\section{Funding}

This work was financially supported through grants from the National Natural Science Foundation of China (81873450), and the Open Research Fund from Beijing Advanced Innovation Center for Big Data-Based Precision Medicine, Beijing Tongren Hospital, Beihang University \& Capital Medical University (Grant No. BHTR-KFJJ-202009), to L. W. KHY was supported by High-Throughput Molecular Diagnostics, Seattle Genetics, Gilead Pharmaceutical, Incyte Pharmaceutical, Genomic testing diagnostics, and Roche Molecular Systems.
Availability of data and materials

The datasets supporting the conclusions of this study are included in the figures and tables.

\section{Ethics approval and consent to participate}

The study was approved by as being of no risk or as exempt by the institutional review board of each participating institution.

\section{Consent for publication}

Consent.

\section{Competing interests}

All authors declare no conflicts of interest.

\section{Author details}

1 Department of Hematology, Beijing TongRen Hospital, Capital Medical University, Beijing 100730, China. ${ }^{2}$ Beijing Advanced Innovation Center for Big Data-Based Precision Medicine, Beihang University \& Capital Medical University, Beijing TongRen Hospital, Beijing 100730, China. ${ }^{3}$ Peking Union Medical College Hospital, Beijing 100560, China. ${ }^{4}$ Division of Hematopathology, Department of Pathology, Duke University Medical Center and Cancer Institute, Durham, NC 27710, USA.

Received: 26 August 2020 Accepted: 24 November 2020 Published online: 14 December 2020

\section{References}

1. Siegel RL, Miller KD, Jemal A. Cancer statistics, 2019. CA Cancer J Clin. 2019;69(1):7-34. https://doi.org/10.3322/caac.21551.

2. Morrison VA, Bell JA, Hamilton L, Ogbonnaya A, Shih H-C, Hennenfent $\mathrm{K}$, et al. Economic burden of patients with diffuse large B-cell and follicular lymphoma treated in the USA. Future Oncol. 2018;14(25):2627-42. https://doi.org/10.2217/fon-2018-0267.

3. Miao Y, Li Y, Li J, Young KH. Genetic alterations and their clinical implications in DLBCL. Nat Rev Clin Oncol. 2019;16(10):634-52. https://doi. org/10.1038/s41571-019-0225-1. 
4. Offner F, Samoilova O, Osmanov E, Eom HS, Topp MS, Raposo J, et al. Frontline rituximab, cyclophosphamide, doxorubicin, and prednisone with bortezomib (VR-CAP) or vincristine (R-CHOP) for non-GCB DLBCL. Blood. 2015;126(16):1893-901. https://doi.org/10.1182/blood-2015-03632430.

5. Nowakowski GS, Chiappella A, Witzig TE, Spina M, Gascoyne RD, Zhang $\mathrm{L}$, et al. ROBUST: Lenalidomide-R-CHOP versus placebo-R-CHOP in previously untreated $\mathrm{ABC}$-type diffuse large B-cell lymphoma. Future Oncol. 2016:12(13):1553-63. https://doi.org/10.2217/fon-2016-0130.

6. Younes A, Sehn LH, Johnson P, Zinzani PL, Hong X, Zhu J, et al. Randomized phase III trial of ibrutinib and rituximab plus cyclophosphamide, doxorubicin, vincristine, and prednisone in non-germinal center B-cell diffuse large B-cell lymphoma. J Clin Oncol. 2019;37(15):1285-95. https://doi.org/10.1200/JCO.18.02403.

7. Bartlett NL, Wilson WH, Jung SH, Hsi ED, Maurer MJ, Pederson LD, et al. Dose-adjusted EPOCH-R compared with R-CHOP as frontline therapy for diffuse large B-cell lymphoma: clinical outcomes of the phase III intergroup trial alliance/CALGB 50303. J Clin Oncol. 2019;37(21):1790-9. https://doi.org/10.1200/JCO.18.01994.

8. Coiffier B, Thieblemont C, Van Den Neste E, Lepeu G, Plantier I, Castaigne $\mathrm{S}$, et al. Long-term outcome of patients in the LNH-98.5 trial, the first randomized study comparing rituximab-CHOP to standard $\mathrm{CHOP}$ chemotherapy in DLBCL patients: a study by the Groupe d'Etudes des Lymphomes de l'Adulte. Blood. 2010;116(12):2040-5. https://doi. org/10.1182/blood-2010-03-276246.

9. Crump M, Neelapu SS, Farooq U, Van Den Neste E, Kuruvilla J, Westin J, et al. Outcomes in refractory diffuse large B-cell lymphoma: results from the international SCHOLAR-1 study. Blood. 2017;130(16):1800-8. https ://doi.org/10.1182/blood-2017-03-769620.

10. Neelapu SS, Locke FL, Bartlett NL, Lekakis LJ, Miklos DB, Jacobson CA, et al. Axicabtagene ciloleucel CAR T-cell therapy in refractory large B-cell lymphoma. N Engl J Med. 2017;377(26):2531-44. https://doi. org/10.1056/NEJMoa1707447.

11. Schuster SJ, Svoboda J, Chong EA, Nasta SD, Mato AR, Anak O, et al. Chimeric antigen receptor $T$ cells in refractory B-cell lymphomas. N Engl J Med. 2017:377(26):2545-54. https://doi.org/10.1056/NEJMoa1708566.

12. Schuster SJ, Bishop MR, Tam CS, Waller EK, Borchmann P, McGuirk JP, et al. Tisagenlecleucel in adult relapsed or refractory diffuse large B-cell lymphoma. N Engl J Med. 2019;380(1):45-56. https://doi.org/10.1056/ NEJMoa1804980.

13. Locke FL, Ghobadi A, Jacobson CA, Miklos DB, Lekakis LJ, Oluwole OO, et al. Long-term safety and activity of axicabtagene ciloleucel in refractory large B-cell lymphoma (ZUMA-1): a single-arm, multicentre, phase 1-2 trial. Lancet Oncol. 2019;20(1):31-42. https://doi.org/10.1016/S1470 -2045(18)30864-7.

14. Neelapu SS, Locke FL, Bartlett NL, Lekakis L, Reagan PM, Miklos DB, et al. A Comparison of 2-year outcomes in ZUMA-1 (axicabtagene ciloleucel [Axi-Cel]) and SCHOLAR-1 in patients (Pts) with refractory large B cell lymphoma (LBCL). Biol Blood Marrow Transplant. 2020;26(3):S232. https://doi.org/10.1016/j.bbmt.2019.12.474.

15. Neelapu SS, Locke FL, Bartlett NL, Lekakis L, Miklos DB, Jacobsen ED, et al. Long-term follow-up ZUMA-1: a pivotal trial of axicabtagene ciloleucel (Axi-Cel; KTE-C19) in patients with refractory aggressive nonhodgkin lymphoma (NHL). Blood. 2017;130(Suppl 1):578.

16. Bukhari A, Chaer FE, Koka R, Singh Z, Hutnick E, Ruehle K, et al. Rapid relapse of large B-cell lymphoma after CD19 directed CAR-T-cell therapy due to CD-19 antigen loss. Am J Hematol. 2019;94(10):E273-5. https://doi.org/10.1002/ajh.25591.

17. Hossain N, Sahaf B, Abramian M, Spiegel JY, Kong K, Kim S, et al. Phase I experience with a bi-specific CAR targeting CD19 and CD22 in adults with B-cell malignancies. Blood. 2018;132(Suppl. 1):490. https://doi. org/10.1182/blood-2018-99-110142.

18. Sang W, Shi M, Yang J, Cao J, Xu L, Yan D, et al. Combination of antiCD19 and anti-CD20 chimeric antigen receptor $T$ cells for relapsed and refractory diffuse larger B cell lymphoma: an open-label, single-arm, Phase 1/II Trial. Blood. 2019;134(Supplement_1):1590. https://doi. org/10.1182/blood-2019-127640.

19. Suarez ER, de Chang K, Sun J, Sui J, Freeman GJ, Signoretti S, et al. Chimeric antigen receptor $\mathrm{T}$ cells secreting anti-PD-L1 antibodies more effectively regress renal cell carcinoma in a humanized mouse model.
Oncotarget. 2016;7(23):34341-55. https://doi.org/10.18632/oncotarget .9114.

20. Chong EA, Melenhorst JJ, Svoboda J, Dwivedy Nasta S, Landsburg DJ, Mato AR, et al. Phase I/II study of pembrolizumab for progressive diffuse large B cell lymphoma after anti-CD19 directed chimeric antigen receptor modified T cell therapy. Blood. 2017;130(Supplement 1):4121. https ://doi.org/10.1182/blood.V130.Suppl_1.4121.4121.

21. Ardeshna KM, Marzolini MAV, Norman J, Al-Hajj M, Thomas S, Faulkner J, et al. Phase 1/2 study of AUTO3 the first bicistronic chimeric antigen receptor (CAR) targeting CD19 and CD22 followed by an anti-PD1 in patients with relapsed/refractory $(r / r)$ diffuse large B cell lymphoma (DLBCL): results of cohort 1 and 2 of the Alexander study. Blood. 2019;134(Supplement):246. https://doi.org/10.1182/blood-2019-12272 4.

22. Jacobson CA, Locke FL, Miklos DB, Herrera AF, Westin JR, Lee J, et al. End of phase 1 results from zuma-6: axicabtagene ciloleucel (Axi-Cel) in combination with atezolizumab for the treatment of patients with refractory diffuse large B cell lymphoma. Blood. 2018;132(Supplement 1):4192. https://doi.org/10.1182/blood-2018-99-111523.

23. Benjamin R, Graham C, Yallop D, Jozwik A, Ciocarlie O, Jain N, et al. Preliminary data on safety, cellular kinetics and antileukemic activity of UCART19, an allogeneic anti-CD19 CAR T-cell product, in a pool of adult and pediatric patients with high-risk CD19+ relapsed/refractory B-cell acute lymphoblastic leukemia. Blood. 2018;132(Suppl. 1):896. https:// doi.org/10.1182/blood-2018-99-111356.

24. Liu E, Marin D, Banerjee P, Macapinlac HA, Thompson P, Basar R, et al. Use of CAR-transduced natural killer cells in CD19-positive lymphoid tumors. N Engl J Med. 2020;382(6):545-53. https://doi.org/10.1056/ NEJMoa1910607.

25. Bonifant CL, Jackson HJ, Brentjens RJ, Curran KJ. Toxicity and management in CAR T-cell therapy. Mol Ther Oncolytics. 2016:3:16011. https:// doi.org/10.1038/mto.2016.11.

26. Rodgers DT, Mazagova M, Hampton EN, Cao Y, Ramadoss NS, Hardy IR, et al. Switch-mediated activation and retargeting of CAR-T cells for B-cell malignancies. Proc Natl Acad Sci USA. 2016;113(4):E459-68. https ://doi.org/10.1073/pnas.1524155113.

27. Katz DA, Chu MP, David KA, Thieblemont C, Morley NJ, Khan SS, et al. Open-label, phase 2 study of blinatumomab after first-line rituximabchemotherapy in adults with newly diagnosed, high-risk diffuse large B-cell lymphoma. Blood. 2019;134(Supplement_1):4077. https://doi. org/10.1182/blood-2019-121708.

28. Coyle L, Morley NJ, Rambaldi A, Mason KD, Verhoef G, Furness CL, et al. Open-Label, phase 2 study of blinatumomab as second salvage therapy in adults with relapsed/refractory aggressive B-cell non-Hodgkin lymphoma. Leuk Lymphoma. 2020. https://doi.org/10.1080/10428 194.2020.1759055.

29. Einsele H, Borghaei H, Orlowski RZ, Subklewe M, Roboz GJ, Zugmaier $\mathrm{G}$, et al. The BiTE (bispecific T-cell engager) platform: Development and future potential of a targeted immuno-oncology therapy across tumor types. Cancer. 2020;126(14):3192-201. https://doi.org/10.1002/ cncr.32909.

30. Morschhauser F, Carlo-Stella C, Offner F, Salles GA, Hutchings M, lacoboni G, et al. Dual CD20-targeted therapy with concurrent CD20-TCB and obinutuzumab shows highly promising clinical activity and manageable safety in relapsed or refractory B-cell non-Hodgkin lymphoma: preliminary results from a phase Ib trial. Blood. 2019;134(Supplement_1):1584. https://doi.org/10.1182/blood-2019-123949.

31. Budde LE, Sehn LH, Assouline S, Flinn IW, Isufi I, Yoon S-S, et al. Mosunetuzumab, a full-length bispecific CD20/CD3 antibody, displays clinical activity in relapsed/refractory B-cell non-hodgkin lymphoma (NHL): interim safety and efficacy results from a phase 1 study. Blood. 2018;132(Supplement 1):399. https://doi.org/10.1182/blood-2018-99118344.

32. Bannerji R, Allan JN, Arnason JE, Brown JR, Advani RH, Barnes JA, et al. Clinical activity of REGN1979, a bispecific human, anti-CD20 $\times$ anti-CD3 antibody, in patients with relapsed/refractory (R/R) B-cell non-Hodgkin lymphoma (B-NHL). Blood. 2019;134(Supplement_1):762. https://doi. org/10.1182/blood-2019-122451.

33. Garciaz S, Coso D, Schiano de Colella J-M, Bouabdallah R. Lenalidomide for the treatment of B-cell lymphoma. Expert Opin Investig Drugs. 2016;25(9):1103-16. https://doi.org/10.1080/13543784.2016.1208170. 
34. Castellino A, Chiappella A, LaPlant BR, Pederson LD, Gaidano G, Macon WR, et al. Lenalidomide plus R-CHOP21 in newly diagnosed diffuse large B-cell lymphoma (DLBCL): long-term follow-up results from a combined analysis from two phase 2 trials. Blood Cancer J. 2018:8(11):108.

35. Thieblemont C, Tilly H, Gomes da Silva M, Casasnovas R-O, Fruchart C, Morschhauser $F$, et al. Lenalidomide maintenance compared with placebo in responding elderly patients with diffuse large B-cell lymphoma treated with first-line rituximab plus cyclophosphamide, doxorubicin, vincristine, and prednisone. J Clin Oncol. 2017;35(22):2473-81. https:// doi.org/10.1200/JCO.2017.72.6984.

36. Vitolo U, Witzig TE, Gascoyne RD, Scott DW, Zhang Q, Jurczak W, et al. ROBUST: first report of phase III randomized study of lenalidomide/RCHOP (R2-CHOP) vs placebo/R-CHOP in previously untreated ABC-type diffuse large B-cell lymphoma. Hematol Oncol. 2019;37(S2):36-7. https ://doi.org/10.1002/hon.5_2629.

37. Oberic L, Puyade M, Peyrade F, Maisonneuve H, Abraham J, Feugier $P$, et al. Sub-cutaneous rituximab-minichop versus sub-cutaneous rituximab-minichop + lenalidomide (R2-miniCHOP) in diffuse large B cell lymphoma for patients of 80 years old or more (SENIOR study): a multicentric randomized phase III study of the Lysa. Blood. 2019;134(Supplement_1):352. https://doi.org/10.1182/blood-2019-123612.

38. Nowakowski GS, Hong F, Scott DW, Macon R, King RL, Habermann TM, et al. Addition of lenalidomide to R-chop (R2CHOP) improves outcomes in newly diagnosed diffuse large B-cell lymphoma (DLBCL): first report of ECOG-acrin 1412 a randomized phase 2 us intergroup study of R2CHOP vs R-CHOP. Hematol Oncol. 2019;37(S2):37-8. https://doi. org/10.1002/hon.6_2629.

39. Hernandez-Ilizaliturri FJ, Deeb G, Zinzani PL, Pileri SA, Malik F, Macon $W R$, et al. Higher response to lenalidomide in relapsed/refractory diffuse large B-cell lymphoma in nongerminal center B-cell-like than in germinal center B-cell-like phenotype. Cancer. 2011;117(22):5058-66. https://doi.org/10.1002/cncr.26135.

40. Feldman T, Mato AR, Chow KF, Protomastro EA, Yannotti KM, Bhattacharyya $\mathrm{P}$, et al. Addition of lenalidomide to rituximab, ifosfamide, carboplatin, etoposide (RICER) in first-relapse/primary refractory diffuse large B-cell lymphoma. Br J Haematol. 2014;166(1):77-83. https://doi. org/10.1111/bjh.12846.

41. Martin A, Redondo AM, Dlouhy I, Salar A, Gonzalez-Barca E, Canales $M$, et al. Lenalidomide in combination with R-ESHAP in patients with relapsed or refractory diffuse large B-cell lymphoma: a phase $1 \mathrm{~b}$ study from GELTAMO group. Br J Haematol. 2016;173(2):245-52. https://doi. org/10.1111/bjh.13945.

42. Zinzani PL, Pellegrini C, Argnani L, Broccoli A. Prolonged diseasefree survival in elderly relapsed diffuse large B-cell lymphoma patients treated with lenalidomide plus rituximab. Haematologica. 2016;101(9):e385-6. https://doi.org/10.3324/haematol.2016.147256.

43. Ghesquieres H, Chevrier M, Laadhari M, Chinot O, Choquet S, MoluconChabrot $\mathrm{C}$, et al. Lenalidomide in combination with intravenous rituximab (REVRI) in relapsed/refractory primary CNS lymphoma or primary intraocular lymphoma: a multicenter prospective "proof of concept" phase II study of the French Oculo-Cerebral lymphoma (LOC) Network and the Lymphoma Study Association (LYSA)dagger. Ann Oncol. 2019;30(4):621-8. https://doi.org/10.1093/annonc/mdz032.

44. Rubenstein JL, Geng H, Fraser EJ, Formaker P, Chen L, Sharma J, et al. Phase 1 investigation of lenalidomide/rituximab plus outcomes of lenalidomide maintenance in relapsed CNS lymphoma. Blood Adv. 2018;2(13):1595-607. https://doi.org/10.1182/bloodadvances.20170 14845.

45. Hai-bing Y, Ya-xun W, Nan-nan C, Jie-yu H, Jia-tai W, Kui D, et al. Expression of PD-1 and PD-L1 in diffuse large B-cell lymphoma. Chin J Clin Exp Pathol. 2019:35(4):379-82.

46. Sheikh S, Kuruvilla J. Pembrolizumab for the treatment of diffuse large B-cell lymphoma. Expert Opin Biol Therapy. 2019;19(11):1119-26. https ://doi.org/10.1080/14712598.2019.1659777.

47. Qin $S, X u L$, Yi M, Yu S, Wu K, Luo S. Novel immune checkpoint targets: moving beyond PD-1 and CTLA-4. Mol Cancer. 2019;18(1):155. https:// doi.org/10.1186/s12943-019-1091-2.

48. Lesokhin AM, Ansell SM, Armand P, Scott EC, Halwani A, Gutierrez M, et al. Nivolumab in patients with relapsed or refractory hematologic malignancy: preliminary results of a phase Ib study. J Clin Oncol. 2016;34(23):2698-704. https://doi.org/10.1200/JCO.2015.65.9789.

49. Frigault MJ, Armand P, Redd RA, Jeter E, Merryman RW, Coleman KC, et al. PD-1 blockade for diffuse large B-cell lymphoma after autologous stem cell transplantation. Blood Adv. 2020;4(1):122-6. https://doi. org/10.1182/bloodadvances.2019000784.

50. Smith SD, Till BG, Shadman MS, Lynch RC, Cowan AJ, Wu QV, et al. Pembrolizumab with R-CHOP in previously untreated diffuse large B-cell lymphoma: potential for biomarker driven therapy. Br J Haematol. 2020;189(6):1119-26. https://doi.org/10.1111/bjh.16494.

51. Chao MP, Alizadeh AA, Tang C, Myklebust JH, Varghese B, Gill S, et al. Anti-CD47 antibody synergizes with rituximab to promote phagocytosis and eradicate non-Hodgkin lymphoma. Cell. 2010;142(5):699-713. https://doi.org/10.1016/j.cell.2010.07.044.

52. Advani R, Bartlett NL, Smith SM, Roschewski M, Popplewell L, Flinn I, et al. The first-in-class anti-Cd47 antibody Hu5f9-G4 + rituximab induces durable responses in relapsed/refractory Dlbcl and indolent lymphoma: interim phase 1b/2 results. Hematol Oncol. 2019;37(S2):8990. https://doi.org/10.1002/hon.57_2629.

53. Liu B, Guo H, Xu J, Qin T, Guo Q, Gu N, et al. Elimination of tumor by CD47/PD-L1 dual-targeting fusion protein that engages innate and adaptive immune responses. MAbs. 2018;10(2):315-24. https://doi. org/10.1080/19420862.2017.1409319.

54. Vitolo U, Trněný M, Belada D, Burke JM, Carella AM, Chua N, et al. Obinutuzumab or rituximab plus cyclophosphamide, doxorubicin, vincristine, and prednisone in previously untreated diffuse large B-cell Iymphoma. J Clin Oncol. 2017;35(31):3529-37. https://doi.org/10.1200/ JCO.2017.73.3402.

55. Peyrade F, Bologna S, Delwail V, Emile JF, Pascal L, Fermé C, et al. Combination of ofatumumab and reduced-dose CHOP for diffuse large B-cell lymphomas in patients aged 80 years or older: an open-label, multicentre, single-arm, phase 2 trial from the LYSA group. Lancet Haematol. 2017:4(1):e46-55. https://doi.org/10.1016/S2352-3026(16)30171-5.

56. Flinn IW, Erter J, Daniel DB, Mace JR, Berdeja JG. Phase II study of bendamustine and ofatumumab in elderly patients with newly diagnosed diffuse large B-cell lymphoma who are poor candidates for R-CHOP chemotherapy. Oncologist. 2019;24(8):1035-e623. https://doi. org/10.1634/theoncologist.2019-0286.

57. Fanale MA, Hamlin PA, Park SI, Persky DO, Higgins JP, Burnett C, et al. Safety and efficacy of anti-CD20 immunotoxin MT-3724 in relapsed/ refractory (R/R) B-cell non-Hodgkin lymphoma (NHL) in a phase I study. J Clin Oncol. 2018;36(15_suppl):7580. https://doi.org/10.1200/ JCO.2018.36.15_suppl.7580,

58. Persky DO, Musteata V, Zodelava M, Perekhrestenko T, Diaz AE, Guthrie TH, et al. A phase 2 study of MT-3724 to evaluate safety, pharmacodynamics and efficacy of MT-3724 for the treatment of patients with relapsed or refractory diffuse large B-cell lymphoma. Blood. 2019;134(Supplement_1):5324. https://doi.org/10.1182/blood-2019128604.

59. Persky DO, Miller TP, Unger JM, Spier CM, Puvvada S, Stea BD, et al. Ibritumomab consolidation after 3 cycles of CHOP plus radiotherapy in high-risk limited-stage aggressive B-cell lymphoma: SWOG S0313. Blood. 2015;125(2):236-41. https://doi.org/10.1182/blood-2014-06584623.

60. Persky DO, Li H, Stephens DM, Park SI, Bartlett NL, Swinnen L, et al. PETdirected therapy for patients with limited-stage diffuse large B-cell lymphoma-results of intergroup Nctn study S1001. Blood. 2019;134(Supplement_1):349. https://doi.org/10.1182/blood-2019-123871.

61. Friedberg JW, Unger JM, Burack WR, Gopal AK, Raju RN, Nademanee AP, et al. R-CHOP with iodine-131 tositumomab consolidation for advanced stage diffuse large B-cell lymphoma (DLBCL): SWOG S0433. Br J Haematol. 2014;166(3):382-9. https://doi.org/10.1111/bjh.12906.

62. Morin RD, Assouline S, Alcaide M, Mohajeri A, Johnston RL, Chong $\mathrm{L}$, et al. Genetic landscapes of relapsed and refractory diffuse large B-cell lymphomas. Clin Cancer Res. 2016;22(9):2290-300. https://doi. org/10.1158/1078-0432.CCR-15-2123.

63. Sehn LH, Matasar MJ, Flowers CR, Kamdar M, McMillan AK, Hertzberg $M$, et al. Polatuzumab vedotin plus bendamustine with rituximab in relapsed/refractory diffuse large B-cell lymphoma: updated results of a phase Ib/II randomized study. Blood. 2019;134(Supplement_1):4081. https://doi.org/10.1182/blood-2019-123449. 
64. Tilly H, Morschhauser F, Bartlett NL, Mehta A, Salles G, Haioun C, et al. Polatuzumab vedotin in combination with immunochemotherapy in patients with previously untreated diffuse large B-cell lymphoma: an open-label, non-randomised, phase 1b-2 study. Lancet Oncol. 2019;20(7):998-1010. https://doi.org/10.1016/S1470-2045(19)30091-9.

65. Morschhauser F, Flinn IW, Advani R, Sehn LH, Diefenbach C, Kolibaba $\mathrm{K}$, et al. Polatuzumab vedotin or pinatuzumab vedotin plus rituximab in patients with relapsed or refractory non-Hodgkin lymphoma: final results from a phase 2 randomised study (ROMULUS). Lancet Haematol. 2019;6(5):e254-65. https://doi.org/10.1016/S2352-3026(19)30026-2.

66. Tilly H, Flowers C, Friedberg JW, Herbaux C, Morschhauser F, Sehn LH, et al. POLARIX: a phase 3 study of polatuzumab vedotin (pola) plus R-CHP versus $R-C H O P$ in patients (pts) with untreated DLBCL. J Clin Oncol. 2019;37(15 suppl):TPS7571-TPS. https://doi.org/10.1200/ JCO.2019.37.15_suppl.TPS7571.

67. McMillan AK, Matasar MJ, Sancho J-M, Viardot A, Hernandez J, Perretti T, et al. POLARGO: a randomized phase III study evaluating polatuzumab vedotin plus rituximab, gemcitabine, and oxaliplatin in patients with relapsed/refractory diffuse large B-cell lymphoma who had received one or more previous therapies. Blood. 2019;134(Supplement_1):5317. https://doi.org/10.1182/blood-2019-123673.

68. Jurczak W, Zinzani PL, Hess G, Gaidano G, Provencio M, Nagy Z, et al. A phase lla, open-label, multicenter study of single-agent tafasitamab (MOR208), an Fc-optimized anti-CD19 antibody, in patients with relapsed or refractory B-cell non-Hodgkin's lymphoma: long-term follow-up, final analysis. Blood. 2019;134(Supplement 1):4078. https:// doi.org/10.1182/blood-2019-124297.

69. Düll J, Maddocks KJ, González-Barca E, Jurczak W, Liberati AM, de Vos S, et al., editors. Subgroup analyses from L-MIND, a Phase II study of tafasitamab (MOR208) combined with lenalidomide in patients with relapsed or refractory diffuse large B-cell lymphoma. ASH Annual Meeting and; 2019 December 7, 2019. Orlando, Florida: American Society of Hematology.

70. Ohmachi K, Ogura M, Suehiro Y, Ando K, Uchida T, Choi I, et al. A multicenter phase I study of inebilizumab, a humanized anti-CD19 monoclonal antibody, in Japanese patients with relapsed or refractory B-cell lymphoma and multiple myeloma. Int J Hematol. 2019;109(6):657-64. https://doi.org/10.1007/s12185-019-02635-9.

71. Trněný M, Verhoef G, Dyer MJ, Ben Yehuda D, Patti C, Canales M, et al. A phase II multicenter study of the anti-CD19 antibody drug conjugate coltuximab ravtansine (SAR3419) in patients with relapsed or refractory diffuse large B-cell lymphoma previously treated with rituximab-based immunotherapy. Haematologica. 2018;103(8):1351-8. https://doi. org/10.3324/haematol.2017.168401.

72. Kahl BS, Hamadani M, Radford J, Carlo-Stella C, Caimi P, Reid E, et al. A phase I study of ADCT-402 (Ioncastuximab tesirine), a novel pyrrolobenzodiazepine-based antibody-drug conjugate, in relapsed/refractory B-cell non-hodgkin lymphoma. Clin Cancer Res. 2019;25(23):6986-94. https://doi.org/10.1158/1078-0432.CCR-19-0711.

73. Leonard JP. Epratuzumab, a humanized anti-CD22 antibody, in aggressive non-Hodgkin's lymphoma: phase I/II clinical trial results. Clin Cancer Res. 2004;10(16):5327-34. https://doi.org/10.1158/1078-0432. CCR-04-0294.

74. Leonard JP, Coleman M, Ketas J, Ashe M, Fiore JM, Furman RR, et al. Combination antibody therapy with epratuzumab and rituximab in relapsed or refractory non-Hodgkin's lymphoma. J Clin Oncol. 2005;23(22):5044-51. https://doi.org/10.1200/JCO.2005.13.821.

75. Micallef INM, Maurer MJ, Wiseman GA, Nikcevich DA, Kurtin PJ, Cannon MW, et al. Epratuzumab with rituximab, cyclophosphamide, doxorubicin, vincristine, and prednisone chemotherapy in patients with previously untreated diffuse large B-cell lymphoma. Blood. 2011;118(15):4053-61. https://doi.org/10.1182/blood-2011-02-336990.

76. Fayad L, Offner F, Smith MR, Verhoef G, Johnson P, Kaufman JL, et al. Safety and clinical activity of a combination therapy comprising two antibody-based targeting agents for the treatment of non-Hodgkin lymphoma: results of a phase I/II study evaluating the immunoconjugate inotuzumab ozogamicin with rituximab. J Clin Oncol. 2013;31(5):573-83. https://doi.org/10.1200/JCO.2012.42.7211.

77. Dang NH, Ogura M, Castaigne S, Fayad LE, Jerkeman M, Radford J, et al. Randomized, phase 3 trial of inotuzumab ozogamicin plus rituximab versus chemotherapy plus rituximab for relapsed/refractory aggressive
B-cell non-Hodgkin lymphoma. Br J Haematol. 2018;182(4):583-6. https ://doi.org/10.1111/bjh.14820.

78. Kim SJ, Yoon DH, Kim JS, Kang HJ, Lee HW, Eom H-S, et al. Efficacy of brentuximab vedotin in relapsed or refractory high-CD30-expressing non-hodgkin lymphomas: results of a multicenter, open-labeled phase II trial. Cancer Res Treat. 2019;52(2):374-87.

79. Hu S, Xu-Monette ZY, Balasubramanyam A, Manyam GC, Visco C, Tzankov A, et al. CD30 expression defines a novel subgroup of diffuse large B-cell lymphoma with favorable prognosis and distinct gene expression signature: a report from the International DLBCL RituximabCHOP Consortium Program Study. Blood. 2013;121(14):2715-24. https ://doi.org/10.1182/blood-2012-10-461848.

80. Jacobsen ED, Sharman JP, Oki Y, Advani RH, Winter JN, Bello CM, et al. Brentuximab vedotin demonstrates objective responses in a phase 2 study of relapsed/refractory DLBCL with variable CD30 expression. Blood. 2015;125(9):1394-402. https://doi.org/10.1182/blood-2014-09598763.

81. Bartlett NL, Smith MR, Siddiqi T, Advani RH, O'Connor OA, Sharman JP, et al. Brentuximab vedotin activity in diffuse large B-cell lymphoma with CD30 undetectable by visual assessment of conventional immunohistochemistry. Leukemia Lymphoma. 2017;58(7):1607-16. https:// doi.org/10.1080/10428194.2016.1256481.

82. Zhao S, Molina A, Yu A, Hanson J, Cheung H, Li X, et al. High frequency of CD74 expression in lymphomas: implications for targeted therapy using a novel anti-CD74-drug conjugate. J Pathol Clin Res. 2019;5(1):1224. https://doi.org/10.1002/cjp2.114.

83. Shah NN, Krishnan AY, Shah ND, Burke JM, Melear JM, Spira Al, et al. Preliminary results of a phase 1 dose escalation study of the first-in-class anti-CD74 antibody drug conjugate (ADC), STRO-001, in patients with advanced B-cell malignancies. Blood. 2019;134(Supplement_1):5329. https://doi.org/10.1182/blood-2019-122754.

84. Alizadeh AA, Eisen MB, Davis RE, Ma C, Lossos IS, Rosenwald A, et al. Distinct types of diffuse large B-cell lymphoma identified by gene expression profiling. Nature. 2000;403:503-11.

85. Schmitz R, Wright GW, Huang DW, Johnson CA, Phelan JD, Wang JQ, et al. Genetics and pathogenesis of diffuse large B-cell lymphoma. N Engl J Med. 2018;378(15):1396-407. https://doi.org/10.1056/NEJMo a1801445.

86. Chapuy B, Stewart C, Dunford AJ, Kim J, Kamburov A, Redd RA, et al. Molecular subtypes of diffuse large $B$ cell lymphoma are associated with distinct pathogenic mechanisms and outcomes. Nat Med. 2018;24(5):679-90. https://doi.org/10.1038/s41591-018-0016-8.

87. Wright GW, Huang DW, Phelan JD, Coulibaly ZA, Roulland S, Young RM, et al. A probabilistic classification tool for genetic subtypes of diffuse large B cell lymphoma with therapeutic implications. Cancer Cell. 2020;37(4):551-68.e14. https://doi.org/10.1016/j.ccell.2020.03.015.

88. Wang W-G, Cui W-L, Wang L, Zhu F, Wan X-C, Ping B, et al. Loss of B-cell receptor expression defines a subset of diffuse large $b$-cell lymphoma characterized by silent BCR/PI3K/AKT signaling and a germinal center phenotype displaying low-risk clinicopathologic features. Am J Surg Pathol. 2015;39(7):902-11.

89. Flinn IW, Bartlett NL, Blum KA, Ardeshna KM, LaCasce AS, Flowers CR, et al. A phase II trial to evaluate the efficacy of fostamatinib in patients with relapsed or refractory diffuse large B-cell lymphoma (DLBCL). Eur J Cancer. 2016;54:11-7.

90. Burke JM, Shustov A, Essell J, Patel-Donnelly D, Yang J, Chen R, et al. An open-label, phase II trial of entospletinib (GS-9973), a selective spleen tyrosine kinase inhibitor, in diffuse large B-cell lymphoma. Clin Lymphoma Myeloma Leukemia. 2018;18(8):e327-31. https://doi. org/10.1016/j.clml.2018.05.022.

91. Nagel D, Bognar M, Eitelhuber AC, Kutzner K, Vincendeau M, Krappmann D. Combinatorial BTK and MALT1 inhibition augments killing of CD79 mutant diffuse large B cell lymphoma. Oncotarget. 2015;6(39):42232-42. https://doi.org/10.18632/oncotarget.6273.

92. Wilson WH, Young RM, Schmitz R, Yang Y, Pittaluga S, Wright G, et al. Targeting $B$ cell receptor signaling with ibrutinib in diffuse large $B$ cell lymphoma. Nat Med. 2015;21(8):922-6. https://doi.org/10.1038/ nm.3884.

93. Sauter CS, Matasar MJ, Schoder H, Devlin SM, Drullinsky P, Gerecitano J, et al. A phase 1 study of ibrutinib in combination with R-ICE in patients 
with relapsed or primary refractory DLBCL. Blood. 2018;131 (16):1805-8. https://doi.org/10.1182/blood-2017-08-802561.

94. Zhang SQ, Smith SM, Zhang SY, Lynn WY. Mechanisms of ibrutinib resistance in chronic lymphocytic leukaemia and non-Hodgkin lymphoma. Br J Haematol. 2015;170(4):445-56. https://doi.org/10.1111/ bjh. 13427.

95. Batlevi CL, De Frank S, Stewart C, Hamlin PA, Matasar MJ, Gerecitano JF, et al. Phase I/II clinical trial of ibrutinib and buparlisib in relapsed/ refractory diffuse large B-cell lymphoma, mantle cell lymphoma, and follicular lymphoma. J Clin Oncol. 2018;36(15_suppl):7520. https://doi. org/10.1200/JCO.2018.36.15_suppl.7520.

96. Dyer MJ, De Vos S, Ruan J, Flowers C, Maddocks KJ, Rule S, et al. Acalabrutinib monotherapy in patients (pts) with relapsed/refractory (R/R) diffuse large B-cell lymphoma (DLBCL). J Clin Oncol. 2018;36(15_suppl):7547.

97. Witzig TE, Maddocks KJ, De Vos S, Lyons RM, Edenfield WJ, Sharman $J \mathrm{P}$, et al. Phase $1 / 2$ trial of acalabrutinib plus pembrolizumab (Pem) in relapsed/refractory ( $r / r)$ diffuse large B-cell lymphoma (DLBCL). J Clin Oncol. 2019;37(15_suppl):7519. https://doi.org/10.1200/ JCO.2019.37.15_suppl.7519.

98. Hainsworth JD, Arrowsmith ER, McCleod M, Hsi ED, Hamid O, Shi P, et al. A randomized, phase 2 study of R-CHOP plus enzastaurin vs R-CHOP in patients with intermediate- or high-risk diffuse large B-cell lymphoma. Leukemia Lymphoma. 2016;57(1):216-8. https://doi.org/10.3109/10428 194.2015.1045898.

99. Zhu J, Nowakowski G, Zhang Q, Brody J, Sun X, Maly J, et al. Engine: phase III randomized study of enzastaurin/R-CHOP versus Placebo/R$\mathrm{CHOP}$ in frontline high risk diffuse large $\mathrm{B}$ cell lymphoma patients with novel genomic biomarker DGM1. Blood. 2019;134(Supplement_1):5330. https://doi.org/10.1182/blood-2019-124930.

100. Vaux DL, Cory S, Adams JM. BCl-2 gene promotes haemopoietic cell survival and cooperates with c-myc to immortalize pre-B cells. Nature. 1988:335:440.

101. Davids MS, Roberts AW, Seymour JF, Pagel JM, Kahl BS, Wierda WG, et al. Phase I first-in-human study of venetoclax in patients with relapsed or refractory non-hodgkin lymphoma. J Clin Oncol. 2017;35(8):826-33. https://doi.org/10.1200/JCO.2016.70.4320.

102. Zelenetz AD, Salles G, Mason KD, Casulo C, Le Gouill S, Sehn LH, et al. Venetoclax plus R- or G-CHOP in non-Hodgkin lymphoma: results from the CAVALLI phase 1b trial. Blood. 2019;133(18):1964-76. https://doi. org/10.1182/blood-2018-11-880526.

103. Hughes ME, Landsburg DJ, Rubin DJ, Schuster SJ, Svoboda J, Gerson $J \mathrm{~N}$, et al. Treatment of patients with relapsed/refractory non-hodgkin lymphoma with venetoclax: a single-center evaluation of off-label use. Clin Lymphoma Myeloma Leukemia. 2019;19(12):791-8. https://doi. org/10.1016/j.clml.2019.09.612.

104. Ackler S, Mitten M, Chen J, Clarin J, Foster K, Jin S, et al. Navitoclax (ABT263) and bendamustine \pm rituximab induce enhanced killing of nonHodgkin's lymphoma tumours in vivo. Br J Pharmacol. 2012;167(4):88191. https://doi.org/10.1111/j.1476-5381.2012.02048.x.

105. Seymour JF, Pfreundschuh M, Trněný M, Sehn LH, Catalano J, Csinady E, et al. R-CHOP with or without bevacizumab in patients with previously untreated diffuse large B-cell lymphoma: final MAIN study outcomes. Haematologica. 2014;99(8):1343-9. https://doi.org/10.3324/haema tol.2013.100818.

106. Ma X, Li L, Zhang L, Fu X, Li X, Wang X, et al. Apatinib in patients with relapsed or refractory diffuse large $B$ cell lymphoma: a phase II, open-label, single-arm, prospective study. Drug Des Dev Therapy. 2020;14:275-84. https://doi.org/10.2147/DDDT.S227477.

107. Yin $\mathrm{H}$, Zhong F, Ouyang Y, Wang Q, Ding L, He S. Upregulation of ADAM12 contributes to accelerated cell proliferation and cell adhesionmediated drug resistance (CAM-DR) in non-Hodgkin's lymphoma. Hematology (Amsterdam, Netherlands). 2017;22(9):527-35. https://doi. org/10.1080/10245332.2017.1312205.

108. Lenz G, Hawkes E, Verhoef G, Haioun C, Lim ST, Heo DS, et al. Singleagent activity of phosphatidylinositol 3-kinase inhibition with copanlisib in patients with molecularly defined relapsed or refractory diffuse large B-cell lymphoma. Leukemia. 2020;38:1-14.

109. Coleman M, Belada D, Casasnovas R-O, Gressin R, Lee H-P, Mehta A, et al. Phase 2 study of parsaclisib (INCB050465) for relapsed or refractory diffuse large b-cell lymphoma (DLBCL) (CITADEL-202). J Clin Oncol. 2019;37(15_suppl):e19038-e. https://doi.org/10.1200/JCO.2019.37.15_ suppl.e19038.

110. Witzig TE, Reeder CB, LaPlant BR, Gupta M, Johnston PB, Micallef IN, et al. A phase II trial of the oral mTOR inhibitor everolimus in relapsed aggressive lymphoma. Leukemia. 2011;25(2):341-7. https://doi. org/10.1038/leu.2010.226.

111. Smith SM, van Besien K, Karrison T, Dancey J, McLaughlin P, Younes A, et al. Temsirolimus has activity in non-mantle cell non-Hodgkin's lymphoma subtypes: the University of Chicago phase II consortium. J Clin Oncol. 2010;28(31):4740-6. https://doi.org/10.1200/JCO.2010.29.2813.

112. Barnes JA, Jacobsen E, Feng Y, Freedman A, Hochberg EP, LaCasce AS, et al. Everolimus in combination with rituximab induces complete responses in heavily pretreated diffuse large B-cell lymphoma. Haematologica. 2013;98(4):615-9. https://doi.org/10.3324/haema tol.2012.075184.

113. Witzig TE, Tobinai K, Rigacci L, Ikeda T, Vanazzi A, Hino M, et al. Adjuvant everolimus in high-risk diffuse large B-cell lymphoma: final results from the PILLAR-2 randomized phase III trial. Ann Oncol. 2018;29(3):707-14. https://doi.org/10.1093/annonc/mdx764.

114. Witzig TE, LaPlant B, Habermann TM, MCPhail E, Inwards DJ, Micallef IN, et al. High rate of event-free survival at 24 months with everolimus/ RCHOP for untreated diffuse large B-cell lymphoma: updated results from NCCTG N1085 (Alliance). Blood Cancer J. 2017;7(6):e576-e. https:// doi.org/10.1038/bcj.2017.57.

115. Davis RE, Ngo VN, Lenz G, Tolar P, Young RM, Romesser PB, et al. Chronic active B-cell-receptor signalling in diffuse large B-cell lymphoma. Nature. 2010;463(7277):88-92. https://doi.org/10.1038/nature08638.

116. Dunleavy K, Pittaluga S, Czuczman MS, Dave SS, Wright G, Grant $\mathrm{N}$, et al. Differential efficacy of bortezomib plus chemotherapy within molecular subtypes of diffuse large B-cell lymphoma. Blood. 2009;113(24):6069-76. https://doi.org/10.1182/blood-2009-01-199679.

117. Desai S, Maurin M, Smith MA, Bolick SC, Dessureault S, Tao J, et al. PRDM1 is required for mantle cell lymphoma response to bortezomib. Mol Cancer Res. 2010;8(6):907-18. https://doi.org/10.1158/1541-7786. MCR-10-0131.

118. Xia Y, Xu-Monette ZY, Tzankov A, Li X, Manyam GC, Murty V, et al. Loss of PRDM1/BLIMP-1 function contributes to poor prognosis of activated B-cell-like diffuse large B-cell lymphoma. Leukemia. 2017;31 (3):625-36. https://doi.org/10.1038/leu.2016.243.

119. Goy A, Ramchandren R, Ghosh N, Munoz J, Morgan DS, Dang NH, et al. Ibrutinib plus lenalidomide and rituximab has promising activity in relapsed/refractory non-germinal center B-cell-like DLBCL. Blood. 2019;134(13):1024-36. https://doi.org/10.1182/blood.2018891598.

120. Westin JR, Nastoupil LJ, Fayad L, Hagemeister FB, Oki Y, Turturro F, et al. Smart start: rituximab, lenalidomide, and ibrutinib alone and in combination with standard chemotherapy for patients with newly diagnosed diffuse large B-cell lymphoma: final phase II results. Blood. 2019;134(Supplement_1):1581. https://doi.org/10.1182/blood-2019128475.

121. Huang X, Meng B, lqbal J, Ding BB, Perry AM, Cao W, et al. Activation of the STAT3 signaling pathway is associated with poor survival in diffuse large B-cell lymphoma treated with R-CHOP.J Clin Oncol. 2013;31(36):4520-8. https://doi.org/10.1200/JCO.2012.45.6004.

122. Forero-Torres A, Ramchandren R, Yacoub A, Wertheim M, Edenfield W, Caimi P, et al. Parsaclisib, a potent and highly selective PI3K $\delta$ inhibitor, in patients with relapsed or refractory B-cell malignancies. Blood. 2019;133:blood:2018. https://doi.org/10.1182/blood-2018-08-867499.

123. Kallam A, Witzig TE, Roschewski MJ, Lyden E, Lunning MA, Bierman PJ, et al. Phase II multi-center study of ruxolitinib phosphate for the treatment of relapsed or refractory diffuse large B-cell lymphoma (DLBCL) and peripheral T-cell lymphoma (PTCL). J Clin Oncol. 2019;37(15):e19063-e. https://doi.org/10.1200/JCO.2019.37.15_suppl .e19063.

124. Reilley MJ, McCoon P, Cook C, Lyne P, Kurzrock R, Kim Y, et al. STAT3 antisense oligonucleotide AZD9150 in a subset of patients with heavily pretreated lymphoma: results of a phase $1 \mathrm{~b}$ trial. J Immunother Cancer. 2018;6(1):119. https://doi.org/10.1186/s40425-018-0436-5.

125. Ben-Barouch S, Kuruvilla J. Selinexor (KTP-330) - a selective inhibitor of nuclear export (SINE): anti-tumor activity in diffuse large B-cell lymphoma (DLBCL). Expert Opin Investig Drugs. 2020;29(1):15-21. https ://doi.org/10.1080/13543784.2020.1706087. 
126. Kalakonda N, Maerevoet M, Cavallo F, Follows G, Goy A, Vermaat JSP, et al. Selinexor in patients with relapsed or refractory diffuse large B-cell lymphoma (SADAL): a single-arm, multinational, multicentre, openlabel, phase 2 trial. Lancet Haematol. 2020;7(7):e511-22. https://doi. org/10.1016/S2352-3026(20)30120-4.

127. Assouline SE, Nielsen TH, Yu S, Alcaide M, Chong L, MacDonald D, et al. Phase 2 study of panobinostat with or without rituximab in relapsed diffuse large B-cell lymphoma. Blood. 2016;128(2):185-94. https://doi. org/10.1182/blood-2016-02-699520.

128. Mondello P, Brea EJ, De Stanchina E, Toska E, Chang AY, Fennell M, et al. Panobinostat acts synergistically with ibrutinib in diffuse large B cell lymphoma cells with MyD88 L265P mutations. JCI Insight. 2018;2(6):114. https://doi.org/10.1172/jci.insight.90196.

129. Herrera AF, Chen L, Popplewell LL, Budde LE, Mei M, Armenian SH, et al. Preliminary results from a phase I trial of pembrolizumab plus vorinostat in patients with relapsed or refractory diffuse large b-cell lymphoma, follicular lymphoma, and hodgkin lymphoma. Blood. 2019;134(Supplement_1):759. https://doi.org/10.1182/blood-2019123163.

130. Italiano A, Soria J-C, Toulmonde M, Michot J-M, Lucchesi C, Varga A, et al. Tazemetostat, an EZH2 inhibitor, in relapsed or refractory B-cell non-Hodgkin lymphoma and advanced solid tumours: a first-in-human, open-label, phase 1 study. Lancet Oncol. 2018;19(5):649-59. https://doi. org/10.1016/S1470-2045(18)30145-1.

131. Morschhauser F, Salles G, McKay P, Tilly H, Schmitt A, Gerecitano J, et al. Interim report from a phase 2 multicenter study of Tazemetostat, an $\mathrm{EZH} 2$ inhibitor, in patients with relapsed or refractory B-cell nonHodgkin lymphomas. Hematol Oncol. 2017;35(S2):24-5. https://doi. org/10.1002/hon.2437_3.

132. Sarkozy C, Morschhauser F, Dubois S, Molina T, Michot J-M, CuillièreDartigues P, et al. A LYSA Phase lb study of tazemetostat (EPZ-6438) plus $\mathrm{R}-\mathrm{CHOP}$ in newly diagnosed diffuse large $\mathrm{B}$ cell lymphoma ( $\mathrm{DLBCL}$ ) patients with poor prognosis features. Clin Cancer Res. 2020. https:// doi.org/10.1158/1078-0432.CCR-19-3741.

133. Bordon Y. Mucosal immunology: microbiota-induced T cells block allergic inflammation. Nat Rev Immunol. 2015;15(8):468. https://doi. org/10.1038/nri3894.

134. Bromberg JEC, Issa S, Bakunina K, Minnema MC, Seute T, Durian M et al. Rituximab in patients with primary CNS lymphoma (HOVON 105/ ALLG NHL 24): a randomised, open-label, phase 3 intergroup study. Lancet Oncol. 2019;20(2):216-28. https://doi.org/10.1016/S1470 -2045(18)30747-2.

135. Hama Y, Banjo T, Honma D, Takata Y, Nosaka E, Shiroishi M, et al. Antitumor effect of the EZH1/2 dual inhibitor valemetostat against diffuse large B-cell lymphoma via modulation of b-cell receptor signaling and c-Myc signaling pathways. Blood. 2019;134(Supplement_1):4642. https ://doi.org/10.1182/blood-2019-125436.
136. Delmore JE, Issa GC, Lemieux ME, Rahl PB, Shi J, Jacobs HM, et al. BET bromodomain inhibition as a therapeutic strategy to target c-Myc. Cell. 2011;146(6):904-17. https://doi.org/10.1016/j.cell.2011.08.017.

137. Boi M, Gaudio E, Bonetti P, Kwee I, Bernasconi E, Tarantelli C, et al. The BET bromodomain inhibitor OTX015 affects pathogenetic pathways in preclinical B-cell tumor models and synergizes with targeted drugs. Clin Cancer Res. 2015;21(7):1628-38. https://doi.org/10.1158/1078-0432. CCR-14-1561.

138. Li W, Gupta SK, Han W, Kundson RA, Nelson S, Knutson D, et al. Targeting MYC activity in double-hit lymphoma with MYC and BCL2 and/or BCL6 rearrangements with epigenetic bromodomain inhibitors. J Hematol Oncol. 2019;12(1):73. https://doi.org/10.1186/s13045-019-0761-2.

139. Abramson JS, Palomba ML, Gordon LI, Lunning MA, Wang ML, Arnason

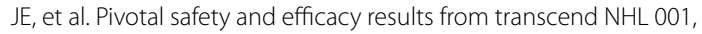
a multicenter phase 1 study of lisocabtagene maraleucel (liso-cel) in relapsed/refractory (R/R) large B cell lymphomas. Blood. 2019;134(Supplement_1):241. https://doi.org/10.1182/blood-2019-127508.

140. He P, Liu H, Liu H, Luo M, Feng H, Li Q, et al. First-in-human study of ET019003, a next generation anti-CD19 T-cell therapy, in patients with relapsed/refractory diffuse large $B$ cell lymphoma $(r / r$ DLBCL). Blood. 2019;134(Supplement_1):2870. https://doi.org/10.1182/blood-2019131414.

141. Kochenderfer JN, Somerville RPT, Lu T, Yang JC, Sherry RM, Feldman SA, et al. Long-duration complete remissions of diffuse large B cell lymphoma after anti-CD19 chimeric antigen receptor $T$ cell therapy. Mol Therapy J Am Soc Gene Therapy. 2017;25(10):2245-53. https://doi. org/10.1016/j.ymthe.2017.07.004.

142. Kraeber-Bodere F, Pallardy A, Maisonneuve H, Campion L, Moreau A, Soubeyran I, et al. Consolidation anti-CD22 fractionated radioimmunotherapy with $90 \mathrm{Y}$-epratuzumab tetraxetan following R-CHOP in elderly patients with diffuse large B-cell lymphoma: a prospective, single group, phase 2 trial. Lancet Haematol. 2017;4(1):e35-45. https://doi. org/10.1016/S2352-3026(16)30168-5.

143. Cavallo F, Follows GA, Goy A, Vermaat J, Casasnovas R-O, Lavee O, et al. Effect of prior therapy on the efficacy and safety of oral selinexor in patients with relapsed/refractory (R/R) diffuse large B-cell lymphoma (DLBCL): a post-hoc analysis of the sadal study. Blood. 2019;134(Supplement_1):5333. https://doi.org/10.1182/blood-2019-122900.

144. Zelenetz AD, Gordon LI, Abramson JS, Advani RH, Bartlett NL, Caimi PF, et al. NCCN guidelines insights: B-cell lymphomas, version 3.2019. J Natl Compr Canc Netw. 2019;17(6):650-61. https://doi.org/10.6004/jnccn .2019.0029.

\section{Publisher's Note}

Springer Nature remains neutral with regard to jurisdictional claims in published maps and institutional affiliations.
Ready to submit your research? Choose BMC and benefit from:

- fast, convenient online submission

- thorough peer review by experienced researchers in your field

- rapid publication on acceptance

- support for research data, including large and complex data types

- gold Open Access which fosters wider collaboration and increased citations

- maximum visibility for your research: over $100 \mathrm{M}$ website views per year

At BMC, research is always in progress.

Learn more biomedcentral.com/submissions 